Discussion Paper No. 08-118

\title{
Market Power, Multimarket Contact and Pricing: \\ Some Evidence from the US Automobile Market
}

Nina Leheyda

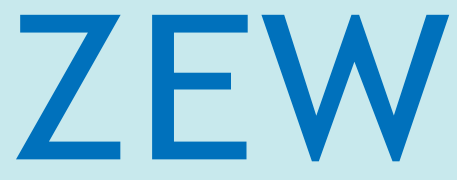

Zentrum für Europäische Wirtschaftsforschung $\mathrm{GmbH}$

Centre for European Economic Research 
Discussion Paper No. 08-118

\title{
Market Power, Multimarket Contact and Pricing: Some Evidence from the US Automobile Market
}

\author{
Nina Leheyda
}

Download this ZEW Discussion Paper from our ftp server:

ftp://ftp.zew.de/pub/zew-docs/dp/dp08118.pdf

Die Discussion Papers dienen einer möglichst schnellen Verbreitung von neueren Forschungsarbeiten des ZEW. Die Beiträge liegen in alleiniger Verantwortung der Autoren und stellen nicht notwendigerweise die Meinung des ZEW dar.

Discussion Papers are intended to make results of ZEW research promptly available to other economists in order to encourage discussion and suggestions for revisions. The authors are solely responsible for the contents which do not necessarily represent the opinion of the ZEW. 


\section{Non-Technical Summary}

Multimarket contact is perceived to be one of those factors, which can facilitate and sustain implicit collusion. This multimarket contact effect has got relatively little attention in the previous literature, although the theoretical and empirical discussion has been revived in the 1990s after Bernheim and Whinston (1990) seminal work. In this paper the authors state that the multimarket contact may lessen the degree of the competition between the rivals, as the multiple competitors are more likely to recognize their mutual dependence, and to sustain collusion across the range of markets, in which they meet. The existing empirical studies, which are mostly done for airlines and banking industry, have failed to give conclusive evidence about the existence, sign and significance of the multimarket contact effect on collusion.

The present paper attempts to develop new approaches to study the interdependence of firm behaviour across markets, especially in the context of differentiated products industries. In particular, the paper looks at whether the multimarket contact facilitates collusive (cooperative) arrangements, or reduces firm competition intensity.

The multimarket contact effects are studied within a structural oligopoly model for differentiated products for the US automobile market. The automobile industry is characterized by extensive multimarket contact within the geographical and product market context where different firms may have different "spheres of influence". The results of the paper lends some support to the fact that multimarket contact influences competition in the automobile markets and increases the firms' strategic interdependence. 


\section{Das Wichtigste in Kürze}

Der Multi-Markt-Kontakt (,multimarket contact') ist eines der Faktoren, der zu impliziten Kollusion führen könnte. Dieser Multi-Markt-Kontakt-Effekt wurde in der früheren Literatur relativ wenig untersucht, obwohl die theoretische und empirische Diskussion nach der grundlegenden Studie von Bernheim und Whinston (1990) in den 90er Jahren wieder aufgenommen wurde. In diesem Papier behaupten die Autoren, dass der Multi-Markt-Kontakt zu einer Verringerung der Wettbewerbsintensität zwischen den rivalisierenden Unternehmen führen kann, weil es wahrscheinlicher ist, dass die mehrfachen (multiplen) Wettbewerber die wechselseitigen Abhängigkeiten erkennen, und sich kollusiv auf den Märkten, wo sie sich begegnen, verhalten. Den existierenden empirischen Studien, die meistens für die Luftfahrtindustrie und Banken durchgeführt wurden, ist es nicht gelungen, die beweiskräftige Aussage bezüglich der Existenz, des Zeichnens und der Signifikanz des Multi-Markt-KontaktEffektes auf die Kollusion zu machen.

Der Hauptzweck dieser Studie ist die Entwicklung von neuen Methoden zur Erforschung der wechselseitigen Abhängigkeit des Unternehmensverhaltens, besonders im Kontext der Industrien mit heterogenen Produkten. Insbesondere wird untersucht, ob die Zunahme von Multi-Markt-Kontakten zwischen den rivalisierenden Unternehmen zu einer Verringerung der Wettbewerbsintensität oder sogar zu impliziten Kollusion zwischen den Unternehmen führt.

Die Multi-Markt-Kontakt-Hypothese wird für den US-Automobilmarkt durch die Schätzung eines strukturellen Oligopolmodells für heterogene Produkte untersucht. Die Automobilindustrie wird durch den hohen Grad an Multi-Markt-Kontakt auf den geographischen und Produktmärkten bezeichnet. Auf diesen Märkten können die rivalisierenden Unternehmen verschiedene Einflussbereiche (,spheres of influence') haben. Die Ergebnisse dieser Studie unterstützen die Hypothese, dass der Multi-Markt-Kontakt den Wettbewerb auf den Automobilmärkten beeinflussen und die strategische Interdependenz der Unternehmen verstärken könnte. 


\title{
Market Power, Multimarket Contact and Pricing:
}

\section{Some Evidence from the US Automobile Market ${ }^{1}$}

\author{
Nina Leheyda*
}

\begin{abstract}
Multimarket contact is perceived to be one of those factors, which can facilitate and sustain implicit collusive (cooperative) arrangements. This paper attempts to develop new approaches to study the interdependence of firm behaviour across markets, especially in the context of differentiated products industries. I analyse the principle of conducting a test of the mutual forbearance hypothesis, and its application using particular data. The multimarket contact effects are studied within a structural oligopoly model for differentiated products for the US automobile market on the basis of the aggregate product-level data for 2001-2003.

Some support has been found that multimarket contact may influence competition in the automobile market and increase the firms' strategic interdependence. This effect is, however, difficult to disentangle from the effect of the market concentration in the US automobile market (dominance of the market by the American Big Three) on the firm behaviour, which could also facilitate collusion. In other words, it is difficult to argue whether coordination is due to market concentration, or due to multimarket contact, or both. Concentration is argued to foster the slack, which is transferred through the multimarket contact.
\end{abstract}

Keywords: multimarket contact, collusion, automobile industry, test for non-nested hypothesis, menu test, structural oligopoly models

JEL-Classification: L13, L25, L62

* Centre for European Economic Research (ZEW), Department of Industrial Economics and International Management, P.O. Box 1034 43, D-68034 Mannheim, Germany, phone: +49621-1235-172, fax: +49-621-1235-170, leheyda@zew.de

I am thankful for the financial support from the German Research Foundation (Deutsche Forschungsgemeinschaft (DFG)) and the Center for European Economic Research (ZEW) during my doctoral studies at the Center for Doctoral Studies in Economics (CDSE), University of Mannheim. The comments of Georg Licht, Konrad Stahl, Jordi Jaumandreu, Ulrich Kaiser, Andrey Ivanov, Alia Gizatulina, the participants of the CDSE doctoral seminar, ZEW Brown Bag Seminar, 2006 ENTER Jamboree, 2006 SFB Workshop, 2006 IIOC, 2006 EARIE, 2007 1st RNIC conference and the Econometric Society Session during 2007 ESEM-EEA European Joint Meeting were really appreciated. 


\section{Introduction}

Multiple competition, or multimarket contact rivalry, has become very important in the contemporary competitive strategy literature. Multimarket contact is perceived to be one of those factors, which can facilitate and sustain implicit collusion. This multimarket contact effect has got relatively little attention in the previous literature, although the theoretical and empirical discussion has been revived in the 1990s after the seminal paper by Bernheim and Whinston (1990).

The main objective of this paper has been to verify the existence and significance of the effect of the multimarket contact on the tacit collusion, through developing a new methodology, or approaches. The paper addresses two major issues: how to conduct the test of the mutual forbearance hypothesis in principle (to try to solve the problem of the previous inconclusive empirical evidence and address the weaknesses of the previous empirical studies), and how to implement a test using particular data (especially when some multimarket contact measure may not be readily available, or when the desirable situation for observing the multimarket contact effects on cooperative behaviour is not observable, however, the multimarket contact is present in an industry of interest).

Competition policy has exhibited growing interest in empirical oligopoly models to quantify the competitive effects of mergers, study market conduct, estimate the welfare effects of the introduction of new products, investigate deregulation effects, etc. In this paper, the multimarket contact effects on collusion are tested on the basis of the structural oligopoly model for differentiated products and estimated on the basis of the market-level data on prices, quantities, and product characteristics. The differentiated products demand is derived from the discrete choice framework. With a complete specification of the demand and cost conditions, the hypothesis of the mutual forbearance and of the traditional view of no interdependence of the firm behaviour across the markets can be tested directly. Different hypotheses on the firms' equilibrium interactions, including the hypothesis of collusive behaviour due to multimarket contact, are developed and tested in this paper. Non-nested procedures and goodness-of-fit criteria are then applied to choose between different models of the firm behaviour.

The multimarket contact effects on oligopolistic coordination are tested for the automotive industry, on the basis of the product-level data for the US light vehicles market for 20012003. The automotive industry appears to be an interesting case for studying the above mentioned effects as it is characterized by extensive multimarket contact both across the product and geographical markets dimensions. The industry has undergone a significant consolidation process, which resulted in about 13 major independent OEMs, which are present in virtually all market segments and across different geographic regions. In this paper the multimarket contact is defined on a product segment level in the light vehicles market within one geographical market, namely the US market.

The automotive industry has become a subject of empirical studies at the product level starting with Bresnahan (1981), and later a number of studies appearing after Berry (1994) and Berry, Levinsohn and Pakes (1995) papers, relying on the advances in the discrete choice literature. Some automotive industry papers study the equilibrium firm interactions (e.g., Bresnahan, 1981, 1987, Feenstra and Levinsohn, 1995, Verboven, 1996, 1999, Berry, Levinsohn, and Pakes, 1999, Sudhir, 2001, Goldberg and Verboven, 2001, Brenkers and Verboven, 2006), but only a few of them study (directly, or indirectly) collusive behaviour (e.g., Bresnahan, 1981, 1987², Verboven, 1996, Sudhir, 2001, Goldberg and Verboven,

Bresnahan (1981) studies the firm behaviour in the American car market in 1977 and 1978 and estimates the price-cost margins during this period of time, as well as the impact of import competition on the 
$2001^{3}$ ). In the automotive industry studies, which are based upon the estimation of the structural oligopoly models, Bertrand-Nash equilibrium is usually assumed, which may be not quite correct as the repeated interaction among the automotive firms may destroy the Bertrand outcome. The concentrated structure of the industry could also foster cooperative behaviour. In some studies, Cournot equilibrium, or some "mixed" equilibrium (i.e., price and quantity competition for different sets of firms) is estimated (e.g., Feenstra and Levinsohn, 1995, Berry, Levinsohn and Pakes, 1999).

The literature on the firm behaviour pattern in different automotive market segments is scarce, the only exception is the paper by Sudhir (1991). ${ }^{4}$ The author studies the competitive pricing behaviour in the US automobile market in 1981-1990 and competitive interactions in each segment of the market using the conjectural variation approach. The author finds the following firm behaviour patterns: aggressive behaviour in the minicompact and subcompact segments, cooperative behaviour in the compact and mid-size segments, and Bertrand pricing behaviour in the full-size segment. As already mentioned by Bernheim and Whinston (1990), in case of heterogeneous products there may be different degrees of collusion in different markets due to the multimarket contact based on the demand and cost conditions.

In this paper I have found that multimarket contact may influence competition in the automobile market and increase the firms' strategic interdependence. This effect is, however, difficult to disentangle from the effect of the market concentration in the US automobile market (dominance of the market by the American Big Three) on the firm behaviour. In other words, it is difficult to argue whether coordination is due to market concentration, or due to multimarket contact, or if it can be attributed to both. Concentration is argued to foster the slack, which is transferred through the multimarket contact.

This paper is organized in the following way. First I discuss theoretical and empirical literature related to multimarket contact effects on firm behaviour. After an overview of multimarket and multi-firm (multi-brand) linkages in the US automobile market, I move to the description of the empirical oligopoly model, multimarket contact test methodology, and estimation procedure. The paper concludes with the presentation and discussion of the results.

\section{Multimarket contact theory and empirics}

\subsection{Theory}

Multimarket contact (alternatively, multimarket/multiple competition, multipoint rivalry) can be observed in a number of situations: a firm can produce multiple products, or a singleproduct firm can operate in a number of geographical markets or a conglomerate may be represented along several business lines (Bernheim and Whinston, 1990). It is perceived to be one of those factors, which can facilitate and sustain implicit collusion, or facilitate oligopolistic consensus among firms engaged in noncooperative rivalry. From the theoretical point of view, there have been opposing opinions on the impact of the multimarket contact on collusion. On one hand, there is a mutual forbearance hypothesis by Edwards (1955), defined as the situation when the multimarket contact leads to more cooperation in all the markets that are common to the rivals (i.e., strong interdependence across the markets). Besides, there is a view similar to the mutual forbearance hypothesis, "linked oligopoly theory", developed for

margins. Bresnahan (1987) investigates a supply-side shock in the American automobile market in 1995 and attributes this shock to the price war, while in the neighbouring years the firm behaviour could be characterized as collusive.

Verboven (1996) and Goldberg and Verboven (2001) study the European car market.

Brenkers and Verboven (2006) estimate correlation parameters (on the basis of two-level nested logit) across the market segments for the European car market and make some inferences about the competition pattern in each market segment on the basis of these estimated correlation parameters. 
the banking industry by Solomon (1970). According to this theory, the degree of linkage across the (adjacent) markets, or the presence of a firm in the multiple markets, is one of the important determinants of performance in the oligopolistic environment. Oligopolistic coordination can be strengthened as a result of the multimarket contact.

On the other hand contrary to Edwards (1955) and Solomon (1970), according to the more traditional point of view, coordination is due to market concentration (internal factor, structure of the market/technology), and not due to multimarket contact (external factor, firm behaviour) (Scherer and Ross, 1990). The increased concentration in the market creates barriers to entry and expands the possibilities for the interfirm coordination, thus, lowering the rates of entry and exit from the market. According to the strongest form of this approach, the multimarket firms behave like independent firms in each market, where competition is determined only by those market factors.

In general, this aspect of multiple competition, namely the relationship between the multimarket contact and firm behaviour, in particular, reduction in the firm competition intensity/facilitation of the mutual forbearance ${ }^{5}$, or increasing in general the firms' strategic interdependence (multiplicity of products and markets leading to strategic behaviour that otherwise would not be present) has got relatively little attention in the previous literature.

The more recent theoretical literature on the mutual forbearance hypothesis is represented by the contributions by Bernheim and Whinston (1990), Verboven (1998), Spagnolo (1999), and Matsushima (2001). Bernheim and Whinston (1990) state that the multimarket contact may lessen the degree of the competition between the rivals, as the multiple competitors are more likely to recognize their mutual dependence and to sustain collusion across the range of markets in which they meet. The firms can distribute their market power through pooling the incentive constraints across the markets (the so-called strategic effects): they can decrease prices and give up profits in the more collusive markets in order to facilitate collusion, raise prices and increase profits in the more competitive markets, as long as their total profits are maximized.

Bulow, Geanokoplos and Klemperer (1985) study the strategic interaction of firms due to cost- and demand-based linkages across markets. They just state that demand- and costrelated linkages lead to linkages in strategic interaction, however, do not analyze whether multimarket contact may facilitate collusive outcomes. Bernheim and Whinston (1990) do not assume these linkages in order to highlight the strategic linkages across markets. They point out several conditions that lead to multimarket contact fostering collusion: different firms, different markets, and scale economies. "Spheres of influence" could be developed when there are production cost differences across firms, or there are scale economies, which allow the firms to have higher prices and profits. The maintenance of collusive prices may be facilitated in case of a geographically-based reciprocal trade of output. There is an incentive towards multimarket diversification when the markets could be subjected to random shocks that are imperfectly correlated.

Verboven (1998) looks at the relationship between localized competition, multimarket operation and collusive behaviour. In case of localized competition, firms meet with different sets of rivals. As a result, there are problems of private information concerning the past actions of the firms. Strategies with sufficiently lenient punishments should be adopted by firms because of the resulting communication problems. Spagnolo (1999) gives the more general conditions for the effect of the multimarket contact on collusion, and argues that multimarket contact always leads to collusion, irrespective of asymmetries between markets

The terms "mutual forbearance hypothesis", "multimarket contact hypothesis", "linked oligopoly theory" are synonyms in this paper as they are used by different authors to explain essentially the same phenomenon. 
and firms, when a firm's static objective function is strictly concave, which makes the market supergames interdependent: a firm's payoff in each market is dependent upon how it is doing in the other markets. Matsushima (2001) investigates the issue of the multimarket contact under imperfect monitoring, and finds support for the existence of the multimarket contact effect on collusion as well. ${ }^{6}$

\subsection{Empirical evidence}

There have been several experimental studies on the effects of the multimarket contact on collusion. For example, Phillips and Mason (1992) find the experimental support for the game-theoretic predictions by Bernheim and Whinston (1990). In another study, Phillips and Mason (1996) state that due to the multimarket contact, regulatory action in one market will impact the behaviour of firms in the other market. These studies are based upon the comparison of the firm behaviour under single-market and multi-market situations. In particular, Phillips and Mason (1992) first analyze a distinct duopoly setting without any multimarket contact, and then they observe the behaviour of the subject pairs in the experimental markets.

The existing empirical studies (e.g., Heggestand and Rhoades, 1978, Scott, 1982, Evans and Kessides, 1994, Parker and Röller, 1997), which were mostly conducted for the airline and banking industry, have failed to give conclusive evidence about the existence, sign and significance of the multimarket contact effect on collusion. These are mainly the crosssectional studies. They concentrate on testing the multimarket contact effect based on the construction of some multimarket contact measure on the firm's performance (i.e., the socalled reduced-form approach). There have been virtually no studies done on the multimarket contact effect on collusion within a structural model of firm behaviour (the only exceptions are the papers by Jans and Rosenbaum (1996) and Parker and Röller (1997) for the homogenous products ${ }^{7}$ ). A few studies concentrate on the estimation of the "conjectures" as a way to study the mutual forbearance hypothesis, i.e., the reactions of the other firms to the actions of the given firm (e.g., Gelfand and Spiller, $1987^{8}$ ). The existing empirical studies have difficulty in distinguishing between internal (e.g., concentration, demand conditions, barriers to entry) and external effects (e.g., multimarket contact) upon the firm performance (Bernheim and Whinston, 1990).

Longitudinal data surrounding deregulatory episodes are sometimes used to study the effect of multimarket contact on collusion (e.g., Gelfand and Spiller, 1987, Parker and Röller, 1997). Gelfand and Spiller (1987) study the impact of the relaxation of legal entry restrictions in the Uruguayan banking sector on the development of multiproduct oligopolistic practices. Parker and Röller (1997) use the deregulation in the US telecommunications industry to study the multimarket contact effects: they investigate the impact of the movement from monopoly to duopoly situation (e.g., movement to multimarket contact situation) on the market conduct.

6 Recently there has been some emerging theoretical literature stating that multimarket contact may not always facilitate collusion (e.g., Thomas and Willig, 2006). This may be attributed to the imperfect monitoring of adherence to cooperation, which is observed in the situation of asymmetric information about rivals' actions.

7 These papers also involve the construction of the multimarket contact measures.

8 Although the authors argue that they study the mutual forbearance hypothesis in such a way, it seems as if their methodology is more applicable to study the firms' strategic interdependence like Bulow et al. (1985), or to study generally the firms' oligopolistic interactions. Bresnahan (1989) also advises not using the "mutual forbearance language" in case of the "conjectures" estimation. 


\section{Multi-market and multi-firm (multi-brand) linkages in the US automobile market}

\subsection{Market definition}

Market definition is very important in the multimarket contact effects studies: markets should be strictly defined. In general, market boundaries could be outlined on the basis of several approaches. For example, the market boundaries could be delineated by the low cross-price elasticity of demand (on the basis of the econometric estimation of price elasticities). Another important empirical method of the market boundaries delineation is price correlation analysis. Other less frequently used methods are consumer interviews, shock analysis, Granger causality and cointegration tests, etc. (Bishop and Baldauf, 2006).

The cross-price elasticities of demand for cars in a given market segment with respect to the cars in a different market segment are found to be low in the empirical studies. Given that and the industry wisdom about automotive market segmentation the definition of market segments seems to be suitable for the definition of markets, across which the multimarket contact effects could be investigated for the automobile industry. Brenkers and Verboven (2006b) study the market definition in the European car market and find that the segments are the relevant markets for all car classes (subcompact, compact, intermediate, standard/luxury, and sports), except for minivans, for which the relevant market definition should be the aggregate country level, i.e., all new cars. They recommend that competition authorities investigate the impact of their policies for each car market segment separately. Sudhir (2001) finds a different competition pattern across market segments in the US car market as mentioned above. Consumers within each car market segment are expected to be internally homogenous and externally heterogeneous. They may be similar within a market segment on the basis of age, income, lifestyle, brand loyalty, readiness to buy, etc. To sum up, industry analysts and academic researchers support the view that the car market segments constitute distinct submarkets, which differ in consumer demand, technology and competitors' type (RequenaSilvente and Walker, 2005).

With respect to demand linkages in the automobile markets, it is necessary to find out, to what extent the cars from different market segments are substitutes. As it has been mentioned above, the cross-price elasticities with respect to the cars from the other market segments are usually found to be low. Car customers are younger, with lower incomes, and, thus, more price-sensitive in the smaller car market segments and older, with higher incomes, and less price-sensitive in the premium car market segments. Thus, it is unlikely that consumers from a luxury car market segment will switch to a small car/mini car segment when there is a price increase in the luxury car segment, and vice versa. The product substitution between the adjacent markets (e.g., compact and subcompact cars) is more plausible. In addition, the diversity in the price dispersion for different market segments could offer some support for the existence of distinct markets. On the supply side, there are likely to be economies of scale and scope across market segments for the automotive manufacturers, which rely a lot on the minimum efficiency scale to be profitable.

\subsection{Multimarket presence in the US automobile market}

The automobile market offers a nice possibility to study the multimarket contact effects on mutual forbearance across product lines and across geographical dimensions (i.e., the socalled geographic-product markets). The industry consolidation has resulted in a few major independent producers (see Table 1), which operate across a number of geographical markets 
(US, Western Europe, Japan, etc.). ${ }^{9}$ On the other hand, the development of the light trucks market has increased a number of product markets, across which the producers interact.

Table 1: Interdependence of automotive manufacturers

\begin{tabular}{|c|c|c|}
\hline Manufacturer group & Companies and share & Further ownerships \\
\hline \multirow{7}{*}{ GM Group } & Opel/Vauxhall (100\%) & \\
\hline & Saab $(100 \%)$ & \\
\hline & Isuzu (12\%) & \\
\hline & Suzuki (20\%) & Maruti (54\%) \\
\hline & Fuji Heavy (20\%) & \\
\hline & Daewoo $(42 \%)$ & \\
\hline & Fiat $(10 \%)$ & \\
\hline \multirow[t]{5}{*}{ Ford Group } & Aston Martin (100\%) & \\
\hline & Jaguar (100\%) & \\
\hline & Mazda (33\%) & \\
\hline & Volvo (100\%) & \\
\hline & Land Rover (100\%) & \\
\hline \multirow[t]{5}{*}{ DaimlerChrysler Group } & Mercedes-Benz (100\%) & \\
\hline & Chrysler (100\%) & \\
\hline & Smart (100\%) & \\
\hline & Maybach (100\%) & \\
\hline & Mitsubishi (24.7\%) & \\
\hline \multirow[t]{3}{*}{ Fiat Group } & Fiat Auto (90\%) & Alfa (100\%) \\
\hline & & Lancia (100\%) \\
\hline & Ferrari (90\%) & Maserati (100\%) \\
\hline \multirow[t]{3}{*}{ Renault/Nissan Group } & Dacia $(100 \%)$ & \\
\hline & Nissan (44\%) & \\
\hline & Samsung (70.1\%) & \\
\hline \multirow[t]{5}{*}{ VW Group } & Audi (100\%) & Lamborghini (100\%) \\
\hline & Seat (100\%) & \\
\hline & Skoda $(100 \%)$ & \\
\hline & Bugatti (100\%) & \\
\hline & Bentley (100\%) & \\
\hline Toyota & Daihatsu (52\%) & \\
\hline \multirow[t]{2}{*}{ BMW } & Rolls Royce (100\%) & \\
\hline & Mini (100\%) & \\
\hline \multirow[t]{2}{*}{ PSA } & Peugeot (100\%) & \\
\hline & Citroen (100\%) & \\
\hline \multirow[t]{2}{*}{ Hyundai } & Kia $(60 \%)$ & \\
\hline & Asia $(100 \%)$ & \\
\hline \multicolumn{3}{|l|}{ Honda } \\
\hline \multicolumn{3}{|l|}{ Porsche } \\
\hline \multirow[t]{2}{*}{ Rover } & MG & \\
\hline & Triumph, etc. & \\
\hline
\end{tabular}

Source: Deutsche Bank (2004)

$9 \quad$ In recent years there have been continuous changes in the corporate ownership of automobile companies. One of the recent most important changes has been the disengagement of Daimler from Chrysler: the private equity company Cerberus Capital Management L.P. has concluded the deal of purchasing $80.1 \%$ of the Chrysler Group from DaimlerChrysler in August 2007 for USD 7.4 bn. However, the picture of the ownership in Table 1 is relevant for the period of my estimations, i.e., 2001-2003, and I conduct my analysis on the basis of the ownership observed at that time. 
The development of the light vehicles market is, in particular, a peculiar feature of the US automotive industry. At present, the light trucks sales make up about half of the total vehicles market sales in the US, increasing from about 32\% in 1990. The most important market segments in the US are midrange (24.7\% in 2003), pickup (18.1\%) and sports-utility vehicles (SUVs) (26.7\%). The mid-size segment share decreased from $28.3 \%$ in 1999 to $24.7 \%$ in 2003 of the total market sales, which may to a certain degree be attributed to the increased competition from the SUVs. During 2000-2003 there has been an especially vivid trend in the growth of the SUVs market share, and this was the only growing market during 2000-2003, with the total light trucks showing positive growth rates. The other market segments developments have been rather volatile. The shares of the mid-range, traditional, pickup, and van segments declined, and the shares of the small, upscale, and sporty market segments remained stable during 1999-2003. ${ }^{10}$

The picture of the multimarket contact presence in the automobile market can be, to a certain degree, inferred from Table 2. As it can be seen, the car manufacturer groups are present in almost all market segments. The product lines of many automotive manufacturers have become rather similar and their product markets, therefore, overlap. The US traditional car market segment is especially concentrated and is characterized by the high presence of the domestic automotive with only Toyota as an international player having a 13.2\% market share in 2003. C-4 concentration ratio for individual market segments ranges from $65.4 \%$ in the sporty market segment, where the largest number of producers is present, to $100 \%$ in the traditional market segment, with only four producers being present.

Table 2: US light vehicles market: shares of firms in market segments, \%, 2003

\begin{tabular}{lcccccccc}
\hline Group & Small & $\begin{array}{c}\text { Mid- } \\
\text { range }\end{array}$ & Tradition & $\begin{array}{c}\text { Up- } \\
\text { scale }\end{array}$ & $\begin{array}{c}\text { Sporty } \\
\text { Pick- } \\
\text { up }\end{array}$ & Van & SUV \\
\hline Honda & & 17.2 & & 6.6 & 6.4 & & 11.0 & 8.4 \\
GM & 26.9 & 32.5 & 36.3 & 18.4 & 6.1 & 35.2 & 24.3 & 32.0 \\
Daimler/Chrysler & 7.2 & 9.2 & 7.4 & 16.1 & 9.6 & 18.6 & 28.4 & 14.3 \\
Hyundai/Kia & 16.8 & 3.3 & & & 4.2 & & 3.6 & 3.3 \\
VW & & 8.0 & & 2.7 & 1.7 & & 0.3 & 0.4 \\
Ford & 19.4 & 10.8 & 43.0 & 21.3 & 36.7 & 35.5 & 23.2 & 22.2 \\
Toyota & 21.2 & 9.9 & 13.2 & 11.0 & 5.5 & 8.5 & 7.5 & 11.6 \\
Renault/Nissan & 5.6 & 7.3 & & 6.8 & 7.3 & 2.2 & 1.7 & 4.5 \\
Mitsubishi & 2.9 & 1.8 & & & 7.7 & & & 2.1 \\
BMW & & & & 17.0 & 11.3 & & & 0.9 \\
Fiat & & & & 0.1 & 0.3 & & & 0.3 \\
Porsche & 7 & 9 & 4 & 9 & 12 & 5 & 8 & 11 \\
\hline No. firms & 26.9 & 32.5 & 43.0 & 21.3 & 36.7 & 35.5 & 28.4 & 32.0 \\
C-1 & 84.3 & 70.5 & 100 & 72.8 & 65.4 & 97.8 & 86.8 & 80.1 \\
C-4 & GM & GM & Ford & Ford & Ford & GM, & Chrysler, & GM \\
Domination of a & & & & & Ford & GM & \\
market segment & & & & & & & & \\
(C-1 ratio) & & & & & & & &
\end{tabular}

Source: Automotive News Market Data Book, own calculations

10 Some studies have considered the impact of multimarket contact on current market growth rates (e.g., Haveman and Nonnemaker, 2000). The authors argue that the firms' interdependence is strengthened by the growth in the current markets if the firms are present in multiple markets, so that the negative relationship between multimarket contact and the current markets growth rates will be then observed. Evans and Kessides (1994) argue that if the demand growth rates differ across markets, the firms may shift their punishment power from the rapidly to the slowly growing industries. 
The firms occupy different market shares or have different strengths in different market segments (based on "market share dominance"), which may be found due to the difference in the production costs between the firms, or due to the presence of the economies of scale, "home" brand loyalty, first-mover advantage, etc. The American Big Three dominate different product markets. GM dominates (occupies the highest share of the market segment) the small, midrange, pickup and SUVs market segments. Ford has the largest market shares in the traditional, upscale, sporty and pickup market segments, while Chrysler dominates the van market segment. Toyota, though, not dominating any market segment, has the highest market share in the small car market segment. Honda, Hyundai/Kia, VW, Renault/Nissan, Mitsubishi and BMW have a large market share in the mid-range market segment, in the small car market segment, in the midrange car market segment, in the midrange and sporty market segments, in the sporty market segment, and in the upscale market segment, respectively. Thus, it can be argued that producers occupy rather different positions of strength in different markets, notwithstanding the obvious dominance of the automobile market by the American Big Three.

Table 3 gives an overview of the "most important" and "less important" markets for the automobile manufacturers as defined by the shares of the firm's market segment sales in the firm's total sales. The "importance" of the market or "market share dependence" can be also measured by the percentage of the firm's total revenue (or sales) generated from the market. As for the American Big Three, Ford has the highest firm's shares in the pickup and SUVs market segments and has been known for its competitive advantage in the SUV market. For GM, the SUVs and midrange market segments are the most important market segments in terms of the sales. Chrysler has high market shares in the pickup and SUVs market segments and is known to have a competitive advantage in the van segment, where it has the highest share among all the firms. For all American Big Three the SUVs are a very important market segment. For the other car producers, like for example Honda the midrange market segment is the most important market, while BMW gets most of its profits from selling cars in the upscale market. The SUVs market is important for both firms.

Table 3: US light vehicles market: shares of markets segment sales in a firm's total sales, \%, 2003

\begin{tabular}{lccccccccl}
\hline \hline & Small & $\begin{array}{l}\text { Mid- } \\
\text { range }\end{array}$ & $\begin{array}{l}\text { Tradi } \\
\text { tion }\end{array}$ & $\begin{array}{l}\text { Up- } \\
\text { scale }\end{array}$ & $\begin{array}{l}\text { Sporty } \\
\text { up }\end{array}$ & $\begin{array}{l}\text { Pick- } \\
\text { upan }\end{array}$ & $\begin{array}{l}\text { SUV } \\
\text { Share } \\
\text { in total } \\
\text { US } \\
\text { sales }\end{array}$ \\
\hline Honda & & & & & & & & & \\
GM & 9.4 & 28.2 & 2.9 & 4.0 & 0.6 & 22.1 & 7.1 & 29.6 & 30.0 \\
Daimler/Chrysler & 5.1 & 16.4 & 1.2 & 7.2 & 2.1 & 23.9 & 16.9 & 27.2 & 14.1 \\
Hyundai & 44.2 & 21.4 & & & 3.3 & & 7.9 & 23.2 & 3.8 \\
VW & & 85.2 & & 7.2 & 2.1 & & 1.2 & 4.2 & 2.3 \\
Ford & 8.7 & 12.0 & 4.4 & 6.0 & 5.0 & 28.6 & 8.7 & 26.5 & 22.4 \\
Toyota & 19.3 & 22.4 & 2.8 & 6.3 & 1.5 & 13.9 & 5.7 & 28.0 & 11.1 \\
Renault/Nissan & 11.9 & 38.0 & & 9.1 & 4.6 & 8.5 & 2.9 & 25.0 & 4.8 \\
Mitsubishi & 18.8 & 28.9 & & & 15.1 & & & 37.1 & 1.5 \\
BMW & & & & 64.8 & 20.5 & & & 14.7 & 1.7 \\
Fiat & & & & 41.6 & 58.4 & & & 45.5 & 0.2 \\
Porsche & & & & & 54.5 & & & & \\
\hline Share of segment & 10.1 & 25.0 & 2.3 & 6.3 & 3.0 & 18.1 & 8.4 & 26.8 & \\
sales in total US & & & & & & & & & \\
sales & & & & & & & & & \\
\hline \hline
\end{tabular}


To sum up, the US light vehicles market is a very concentrated market, with car manufacturers being present in almost all market segments. The market segments are, however, characterized by different competition intensity and are dominated by different car producers. These and other above described factors should be taken into account while performing a multimarket contact effects test.

\subsection{Multi-firm (multi-brand) linkages in the US automobile market}

Automobile producers do not only meet in multiple markets (both product and geographical). The global automobile market is characterized by the presence of a number of global automotive manufacturer groups owning several brands that dominate the market (see Table 1 above), several horizontal partial ownership arrangements (in particular, a number of European and American automobile companies have become share-holders in several Japanese automobile manufacturers) and different interfirm relationships. ${ }^{11}$ This builds up a very complex picture of interrelationships and ownership structure in the global automotive industry, which certainly influences the firm behaviour. During the last few decades there has been an increasing number of mergers-acquisitions and alliances between the three automotive poles (Europe, US and Japan), as it has been reflected in the declining number of independent automotive manufacturers. The picture of firms' ownership and interactions is a very dynamic one, as it is reflected by the constant changes in the firm ownership and corporate structure. Some most recent examples are DaimlerChrysler de-merger of 2007, although Daimler has retained about 20\% share in Chrysler, or Ford's sale of financially troubled Jaguar and Land Rover brands to Indian automobile producer Tata in 2008.

Collusive behaviour may be facilitated and the independence of firm strategies across markets may be reduced the more firms behave on a corporate basis as opposed to a marketby-market basis. ${ }^{12}$ Corporate groups (no brands) may develop products to compete with rival firms, or they may suffer from "cannibalization”.

Table 4 gives an example of a product policy for VW Group, which includes brands VW, Skoda, Bentley, Bugatti, Audi, Seat, and Lamborghini. This illustrates the complex picture of multiple market presence and ownership structure in the automotive industry. In particular, the VW Group comprises brands with different brand image, both premium and volume brands. The question arises of whether the brands within a manufacturer group compete with each other (especially those only premium or volume brands), i.e., whether they suffer from "cannibalization", or the profits are jointly maximized for the whole manufacturer group.

11 Under interfirm relationships I mean both equity and contractual arrangements among the automotive manufacturers themselves and between the OEMs and their suppliers (e.g., strategic alliances, joint ventures).

12 A number of empirical studies, which do not take into account the effects of partial ownership arrangements (POAs), find some evidence that the degree of collusion is very similar in both Japanese, where POAs are common, and American car markets (e.g., Odagiri and Yamawaki, 1986, Yamawaki, 1989). Some automobile market studies look at the impact of the POAs on market competition. In particular, Alley (1997) finds on the basis of a conjectural variation model, which takes into account POAs and foreign trade that the degree of collusion due to the POAs in the American car market is even higher than in the Japanese car market. The author studies the effect of cross-shareholdings between Japanese and US automobile manufacturers and between Japanese automobile manufacturers during 1979-1994. It has been generally found that cross-ownership leads to a more collusive outcome (e.g., Reynolds and Snapp, 1986, Farrell and Shapiro, 1990). 
Table 4: Product policy of an independent automotive producer: an example of Volkswagen

\begin{tabular}{|c|c|c|c|c|c|c|c|c|c|c|}
\hline & Hatch & Notch & Station & $M P V$ & $\begin{array}{l}\text { Pickup/ } \\
\text { deliverable } \\
\text { van }\end{array}$ & $S U V$ & Sports coupe & $\begin{array}{l}\text { Limousine } \\
\text { coupe }\end{array}$ & Convertible & Roadster \\
\hline Luxury & & Bentley & & & & & $\begin{array}{l}\text { Lamborghini } \\
\text { Bugatti }\end{array}$ & & & Lamborghini \\
\hline Upper & & $\begin{array}{l}\text { VW } \\
\text { Audi }\end{array}$ & & & & & $\begin{array}{l}\text { Bentley } \\
\text { Lamborghini }\end{array}$ & Bentley & & \\
\hline $\begin{array}{l}\text { Upper } \\
\text { middle }\end{array}$ & & Audi & Audi & VW & & VW & & & & \\
\hline Compact & $\begin{array}{l}\text { Audi } \\
\text { VW } \\
\text { Seat }\end{array}$ & $\begin{array}{l}\text { Skoda } \\
\text { Seat }\end{array}$ & $\begin{array}{l}\text { VW } \\
\text { Audi } \\
\text { Skoda }\end{array}$ & $\begin{array}{l}\text { VW } \\
\text { Seat } \\
\text { Audi }\end{array}$ & VW & & & & VW & \\
\hline Small & $\begin{array}{l}\text { VW } \\
\text { Skoda } \\
\text { Seat }\end{array}$ & $\begin{array}{l}\text { VW } \\
\text { Seat } \\
\text { Skoda }\end{array}$ & Skoda & & & & & & & \\
\hline
\end{tabular}

Source: Volkswagen AG 
As related to the presence of global automotive groups in the US automobile market and interbrand competition within those groups, Mercedes and Chrysler ${ }^{13}$ do not compete with each other (relatively weak competition between premium and volume brands is usually expected). Saab's presence in the US automobile market is not that significant, so one can't seriously talk about competition between GM and Saab models. ${ }^{14}$ For the same goes for Ford and Volvo where Volvo is treated as a premium brand in the US automobile market. ${ }^{15}$

The cases of cross-ownership arrangements, all of them between volume brands, as it can be inferred from Table 1 above are Ford (Mazda), GM (Subaru, Suzuki, Isuzu), RenaultNissan, Toyota (Daihatsu), Chrysler (Mitsubishi), GM (Fiat), Hyundai (Kia). Ford and Mazda compete directly in several market segments (small, midrange, sporty, pickup, van and SUVs). As for GM Group, Subaru is present in the midrange market segment, Suzuki is present in the small and SUVs market segments, and Isuzu is present in the SUVs market segment. Chrysler and Mitsubishi's markets overlap in the small, midrange, sporty and SUVs market segments. Hyundai and Kia overlap in the small, midrange, and SUVs market segments.

In this paper the multimarket contact effects are investigated at the level of manufacturer groups taking into account cross-ownership arrangements in the other firms as well. ${ }^{16}$ In addition, I distinguish between multiproduct (brand) and multiproduct (manufacturer group) assumptions while testing equilibrium interactions.

\section{Empirical structural framework for the US automobile market}

\subsection{Demand}

\subsubsection{Utility (McFadden's (1978) utility specification)}

Assume that consumer $i, i=1, \ldots, n$ has utility $u_{i j}=u\left(x_{j}, \xi_{j}, p_{j} ; \theta\right)$ from consuming product $j, j=1, \ldots, J$, where $j=0$ is an outside good, $x_{j}$ and $\xi_{j}$ are observed (e.g., horsepower, engine size) and unobserved (e.g., style, image) product characteristics, $p_{j}$ is the price of product $j$, and $\theta=(\alpha, \beta)$ are the parameters to be estimated.

The linear version of the random indirect utility is given by:

$u_{i j}=\delta_{j}+\varepsilon_{i j}, i=1, \ldots, n, j=0, \ldots, J$

where $\varepsilon_{i j}$ is assumed to be identically and independently distributed across consumers and products.

The mean valuation for product $j$ common to all consumers is:

13 Mercedes and Chrysler belong to DaimlerChrysler Group: they are present together in the upscale and sporty market segments.

14 Saab belongs to the GM Group: it has insignificant shares in the midrange and upscale car market segments.

15 Volvo belongs to Ford Group: it has insignificant market shares in the midrange and SUVs market segments, and 4.5\% market share in the upscale car market segment. Land Rover and Aston Martin also belong to Ford Premier Automotive Group and have very low shares in the SUVs and sporty market segments, respectively.

16 Parker and Roller (1997) is the only paper that investigates the impact of cross-ownership and multimarket contact on the firm behaviour in the mobile phone industry. The more detailed investigation of the interfirm relationships in the automobile industry could be an interesting subject for future research. 
$\delta_{j} \equiv x_{j} \beta-\alpha p_{j}+\xi_{j}$

It is assumed that a consumer purchases one unit of good that brings him the highest utility. Therefore, consumer $i$ purchases one unit of product $j$ if and only if

$u_{i j}>u_{i k}, 0 \leq k \leq J, k \neq j$

Consequently, the probability $s_{i j}$ that the consumer $i$ purchases the product $j$ is:

$S_{i j}=\operatorname{Pr}\left\{\delta_{j}+\varepsilon_{i j}>\delta_{k}+\varepsilon_{i k}, j \neq k\right\}=$

$=\operatorname{Pr}\left\{\varepsilon_{i k}<\varepsilon_{i j}+\delta_{j}-\delta_{k}, j \neq k\right\}=$

$=\int_{-\infty}^{\infty} F_{j}\left(\varepsilon_{i j}+\delta_{j}-\delta_{0}, \ldots, \varepsilon_{i j}, \ldots, \varepsilon_{i j}+\delta_{j}-\delta_{J}\right)$

where $F_{j}$ are the partial derivatives of the joint cumulative distribution function $F$ of $\left(\varepsilon_{i 0}, \ldots, \varepsilon_{i J}\right)$ with respect to its $j$ th argument.

In this paper I present the empirical framework and tests for the mutual forbearance hypothesis on the basis of the one-level nested multinominal logit. ${ }^{17}$

\subsubsection{Nested multinominal logit: one nest}

Utility $u_{i j}$ of household $i$ for product $j$ in group $g$ is given by: $:^{18}$

$u_{i j}=x_{j} \beta-\alpha p_{j}+\xi_{j}+\zeta_{i g}+(1-\delta) \varepsilon_{i j}, j=1, \ldots, I_{g}$

where $\zeta_{i g}+(1-\delta) \varepsilon_{i j}$ is an extreme value random variable.

The $I$ brands (products) are partitioned into $G$ groups: $g=0,1, \ldots, G$, the outside group is group $0 .{ }^{19}$ Let the set (number) of products in a group $g$ be $I_{g}: I_{0}, \ldots, I_{G}$.

The market share of product $j$ in the group $g$ is given by:

$s_{j / g}(\delta, \sigma)=\left(\frac{e^{\delta_{j} /(1-\sigma)}}{D_{g}}\right)$

where $D_{g}=\sum_{j \in I_{g}} e^{\delta_{j} /(1-\sigma)}, 0 \leq \sigma<1$.

The probability of choosing group $g$ among all groups is given by:

$s_{g}(\delta, \sigma)=\frac{D_{g}^{1-\sigma}}{\left[\sum_{g} D_{g}^{1-\sigma}\right]}$

This gives a market share for product $j$ that belongs to group $g$ :

17 It should be noted that simple logit and nested logit models have been used extensively by economists for merger evaluation (e.g., Werden and Froeb, 1994, 2002, Jayaratne and Shapiro, 2000, Ivaldi and Verboven, 2005).

18 In the exposition below I follow Berry (1994).

19 Outside good" does not compete with other goods in the industry, its price or quantity is set exogenously. If there were not for the outside good, everyone would have been forced to purchase an "inside" good. 
$s_{j}(\delta, \sigma)=s_{j / g}(\delta, \sigma) s_{g}(\delta, \sigma)=\frac{e^{\delta_{j} /(1-\sigma)}}{D_{g}} \frac{D_{g}{ }^{1-\sigma}}{\sum_{g} D_{g}^{1-\sigma}}=\frac{e^{\delta_{j} /(1-\sigma)}}{D_{g}^{\sigma} \sum_{g} D_{g}^{1-\sigma}}$

where $\sigma \in[0,1]$ is a measure of the degree of substitution, or the within-group correlation of the utility levels. The lower $\sigma$ means the lower correlation of preferences. $\sigma=0$ implies no correlation of preferences, and consumers may thus switch to the products in another group, which means the standard logit model. $\sigma=1$ implies perfect correlation of preferences for products within the same group, i.e., perfect substitutes. E.g., when a new compact car is introduced, the demand for the other subcompact cars will go down rather than the demand for the cars in the other segments (Ivaldi and Verboven, 2005).

The group 0 has only one outside good, with $\delta_{0} \equiv 0$ (i.e., the utility from consuming the outside good is normalized to zero) and $D_{0}=1$ and with the market share of:

$$
s_{0}(\delta, \sigma)=\frac{1}{\left[\sum_{g} D_{g}^{1-\sigma}\right]}
$$

The inversion procedure for the mean utility level has been suggested by Berry (1994).

Consequently, the following demand equation may be derived by inverting the market share equation:

$\ln \left(s_{j}\right)=\ln \left(s_{0}\right)+x_{j} \beta-\alpha p_{j}+\sigma \ln \left(s_{j / g}\right)+\xi_{j}$

where $s_{j / g}$ is the share of product $j$ in group $g$ (within-group share), $s_{j}$ is the share of product $j$ in the total market, and $s_{0}$ is the proportion of the consumers who choose the outside good.

The own price elasticity $E_{s_{j} / p_{j}}$ of the market share $s_{j}$ of product $j$ is:

$$
E_{s_{j} / p_{j}}=\frac{\partial s_{j}}{\partial p_{j}} \frac{p_{j}}{s_{j}}
$$

with

$$
\begin{aligned}
& \frac{\partial s_{j}}{\partial p_{j}}=\frac{\partial s_{j}}{\partial \delta_{j}} \frac{\partial \delta_{j}}{\partial p_{j}} \\
& \frac{\partial s_{j}}{\partial \delta_{j}}=s_{j} \frac{1}{1-\sigma}\left[1-\sigma s_{j / g}-(1-\sigma) s_{j}\right]
\end{aligned}
$$

Thus, the own-price elasticity can be written down as:

$$
E_{s_{j} / p_{j}}=-\alpha p_{j} \frac{1}{1-\sigma}\left[1-\sigma s_{j / g}-(1-\sigma) s_{j}\right]
$$

The cross-price elasticity $E_{s_{j} / p_{m}}$ of the market share of product $j$ with respect to the price of product $m p_{m}$ is given by:

$$
E_{s_{j} / p_{m}}=\frac{\partial s_{j}}{\partial p_{m}} \frac{p_{m}}{s_{j}}
$$


with

$$
\begin{aligned}
& \frac{\partial s_{j}}{\partial p_{m}}=\frac{\partial s_{j}}{\partial \delta_{m}} \frac{\partial \delta_{m}}{\partial p_{m}} \\
& \frac{\partial s_{j}}{\partial \delta_{m}}=-s_{j}\left(\frac{\sigma}{1-\sigma} s_{m / g}+s_{m}\right)
\end{aligned}
$$

Therefore, the cross-price elasticity is:

$$
E_{s_{j} / p_{m}}=a p_{m}\left(\frac{\sigma}{1-\sigma} S_{m / g}+s_{m}\right)
$$

if $j$ and $m$ belong to the same market segment, and

$$
E_{s_{j} / p_{k}}=\alpha p_{k} s_{k}
$$

if $j$ and $k$ belong to different market segments.

\subsection{Costs and firm behaviour}

\subsubsection{Price competition}

The log-linear marginal cost function is assumed:

$$
\ln \left(c_{j}\right)=w_{j} \gamma+\omega_{j}
$$

where $w_{j}$ and $\omega_{j}$ are observed and unobserved product characteristics, respectively, and $\gamma$ are the parameters to be estimated. ${ }^{20}$

Assume $F$ sellers of a differentiated product. ${ }^{21}$ Firm $f$ produces $J_{f}$ of $F$ total differentiated products. The demand for product $j$ is given by $M s_{j}(p, X ; \theta)$, where $M$ is the market size. Let $P_{J_{f}}$ be the set of prices that the player $f$ sets. Product characteristics for any year are assumed to be exogenous. Assume that the outside good is competitively supplied.

The firm $f$ chooses $P_{J_{f}}$ to maximize its profits, for given $J$ and $p_{j}$ with $j \in J_{f}$ :

$$
\max _{p_{J_{f}}} \pi_{f}=\sum_{j \in J_{f}}\left(p_{j}-c_{j}\right) M s_{j}(p)-\sum_{j \in J_{f}} F_{j}
$$

where $c_{j}$ is the constant marginal cost of brand $j, s_{j}(p)$ is the market share of brand $j$, being a function of all brands' prices, and $F_{j}$ is fixed cost for a product $j$.

The first-order conditions for the manufacturer $f$ 's profit maximization problem are (assuming that pure-strategy Nash equilibrium in prices exists and that prices are strictly positive): ${ }^{22}$

20 The quantity variable $Q_{j}$ may be included to allow for increasing/decreasing returns to scale.

21 In the exposition below I follow Berry, Levinsohn and Pakes (1995).

22

Caplin and Nalebuff (1991) have shown that a pure strategy Nash equilibrium exists in case of singleproduct firms, using a rather general demand model. Anderson and de Palma (1992) have shown the existence of a pure strategy Nash equilibrium in case of multi-product firms using the nested logit demand model. 
$s_{j}(p)+\sum_{r \in J_{f}}\left(p_{r}-c_{r}\right) \frac{\partial s_{r}(p)}{\partial p_{j}}=0$

Let firm $f$ have $k(f)$ products, which are indexed by $j=J_{1}^{f}, \ldots, J_{k(f)}^{f}$, with $J_{1}^{1}=1$ and $J_{k(F)}^{F}=J$.

Define matrix $\Delta_{f}$ as:

$$
\Delta_{f}=\left(\begin{array}{ccc}
\frac{\partial s\left(J_{1}^{f}\right)}{\partial p\left(J_{1}^{f}\right)} & \cdots & \frac{\partial s\left(J_{k(f)}^{f}\right)}{\partial p\left(J_{1}^{f}\right)} \\
\vdots & \ddots & \vdots \\
\frac{\partial s\left(J_{1}^{f}\right)}{\partial p\left(J_{k(f)}^{f}\right)} & \cdots & \frac{\partial s\left(J_{k(f)}^{f}\right)}{\partial p\left(J_{k(f)}^{f}\right)}
\end{array}\right)
$$

In vector notation, the first-order conditions for $J$ total products simultaneously can be written down as:

$$
\left(\begin{array}{c}
s_{1} \\
s_{J}
\end{array}\right)+\left(\begin{array}{ccc}
\Delta^{1} & & 0 \\
& \cdots & \\
0 & & \Delta^{F}
\end{array}\right)\left(\begin{array}{c}
p_{1}-c_{1} \\
p_{j}-c_{j}
\end{array}\right)=0
$$

Assume that $\Omega$ is a non-singular matrix. Therefore, the first-order conditions can be expressed as:

$$
p=c+\Omega^{-1} s
$$

with the marginal cost equation taking up the following form:

$$
\ln \left(p-\Omega^{-1} s\right)=w \gamma+\omega
$$

Within the last equation, the following scenarios can be tested: Bertrand behaviour with single-product firms, Bertrand behaviour with multi-product firms ${ }^{23}$, perfectly collusive (total industry) behaviour, market-segment collusive behaviour, and assumption concerning multimarket contact firm behaviour. This can be done within the menu, or conjectural variations parameters approaches that are discussed below.

The analysis of different price equilibrium assumptions can be done at the market segment level (i.e., case of myopic firms, each firm considers in its profit maximization task only the products of a particular market segment). In this case, the market segments are treated to be independent. The analysis can be also done at the firm level (i.e., case of firms that behave strategically, the firm takes into account the cross-price elasticities of all its products), where the market segments are not independent and the substitution between them is possible. Both scenarios are tested in this paper to choose the pattern of the firm behaviour that best fits the data.

23 If only products of a firm in the same market segment are considered by the firm in the profit maximization task, the explicit expression for the mark-up can be derived. If other products of the firm in the different market segments are considered as well, the whole matrix of market share derivatives with respect to the price has to be inverted to get the markups. The derivatives of products with respect to products in the other market segments are usually found to be low anyway, so that the markups may be not influenced significantly (Verboven, 1996). Verboven (1996) also tests for the presence of market segment-specific collusion. Sudhir (2001) finds a different competition pattern across market segments. 


\subsubsection{Menu approach}

The menu approach is discussed in Bresnahan (1987), Gasmi et al. (1990, 1992) and advocated, in particular, by Nevo (1998). Under this approach, different models of competition may be tested through setting different elements of the ownership matrix to one. The choice among the different models of conduct, which constitute a finite set (defined by a researcher based on his understanding), is done on the basis of "fit" of different models, formally by performing a test of nonnested hypothesis (e.g., Vuong, 1989).

Consequently, the matrix $\Omega^{-1}$ may be written down as $\theta \Delta^{-1}$, where $\Delta^{-1}$ is the matrix of own- and cross-price elasticities, and $\theta$ is an ownership matrix, with $\theta_{i j}=1$ if $i$ and $j$ are produced by the same firm, and 0 otherwise. This is an element-by-element multiplication of matrices of the same dimension.

\subsubsection{Conjectural variations approach}

The conjectural variations approach has been criticized for the problem of the interpretation of the conjectural variations parameters and the problem of identification, especially in case of differentiated products. ${ }^{24}$ The detailed discussion of this approach can be found in Bresnahan (1989) and Nevo (1998). The conjectural variations approach may allow testing for the degree of collusiveness, or competitiveness of a particular market segment/industry, or distinguishing between the more collusive and more competitive markets, not necessarily finding perfect market segment collusion as based on the menu approach.

\section{Methodological framework for testing the multimarket contact effects}

\subsection{Test for the mutual forbearance hypothesis: idea}

The "ideal" test for identifying the multimarket contact effects on collusive behaviour would be to contrast the pricing behaviour in a single-market (e.g., two firms meet each other in one market M1) and a multi-market context (e.g., these two firms move together to another market $\mathrm{M} 1+\mathrm{M} 2)$ to test for incremental effects on the firm behaviour. In addition, one could take into account a certain period of time and compare the break-down of collusive prices in M1 world and M1+M2 world, and if this period of break-downs under the latter scenario is shorter, then this could be a hard test for showing that the multimarket contact presence leads to more collusion.

The automobile industry, although characterized by extensive multimarket contact presence, offers no such "optimal" situations to test for the mutual forbearance hypothesis, and, thus, necessitates the search for other approaches to study the behaviour of the multimarket contact firms. I test for multimarket contact firm coalitions and perform simulations as a way to investigate the multimarket contact effects on the firm behaviour. The idea behind these approaches, which have not been applied before in the multimarket contact studies, is discussed in the next two sections 5.2 and 5.3.

\subsection{Test for the mutual forbearance hypothesis (1): testing collusive assumption among the multimarket contact firms}

As mentioned above, Bernheim and Whinston (1990) state that the multimarket contact may lessen the degree of competition between the rivals as the multiple competitors are more

$24 \quad$ Conjectural variations for the market segments in the automobile industry have been estimated by Sudhir (2001) and constructed for the market segments at the country level by Brenkers and Verboven (2006a). 
likely to recognize their mutual dependence and to sustain collusion across the range of markets in which they meet. The advantage of fierce competition in one market is weighted against the costs of potential retaliations by the competitors in the other markets where they meet each other.

The idea behind the test for the mutual forbearance hypothesis (1) is to test different assumptions/hypotheses concerning the firm behaviour by adjusting the ownership matrix $\theta$ in an appropriate way (see Section 4.2.2) in order to derive the competition pattern in the industry and across market segments, including the possibility of the mutual forbearance hypothesis. The test under this approach can be conducted in two steps:

Step 1. Derive the pricing equation under the multimarket contact assumption using the menu approach, i.e., by specifying a particular ownership matrix.

Taking into account the above theoretical insights about the mutual forbearance hypothesis, the formal test for testing the multimarket effects on prices would be to see whether the multimarket contact firm takes into account the cross-price reactions of the other multimarket contact firms across the markets in its profit-maximization task:

$\max _{p_{J_{M M C}, f \in M M C}} \pi_{f}=\sum_{j \in J_{M M C}, f \in M M C}\left(p_{j}-c_{j}\right) M s_{j}(p)$

where $J_{M M C}$ are all products of multimarket contact firms, including the multimarket contact firm $f$. That is, the joint profit maximization of the products of the multimarket contact firms coalition is assumed (a firm $f$ belongs to the set of the multimarket contact firms $M M C$ ).

The first-order conditions for a multimarket contact firm $f$ that internalizes the cross-price effects with its competitors can be written down as follows:

$s_{j}(p)+\sum_{r \in J_{M M C}, f \in M M C}\left(p_{r}-c_{r}\right) \frac{\partial s_{r}(p)}{\partial p_{j}}=0$

This expression can be specified as market segment-specific (market segments are independent), or industry-specific (market segments are interrelated).

In addition to the multimarket contact specification, the Bertrand-Nash multi-product price specification can be derived not only for the car manufacturers (brand level, e.g., a Mercedes car) but also for the car manufacturer groups (i.e., corporate group, e.g., Mercedes and Chrysler cars of DaimlerChrysler Group) and those car manufacturers that hold shares in the other automotive firms (i.e., cross-ownership arrangements).

Step 2. Test different assumptions about the equilibrium interactions of firms (i.e., singleproduct, multi-product, collusion, collusion due to the multimarket contact), and choose the best supply model among the competing supply-side models on the basis of the goodness-offit of the model (most often R-squared, adjusted R-squared, some information, or prediction criterion), or the test of nonnested hypotheses (e.g., Vuong, 1989). In the absence of publicly available information on marginal costs and price-cost margins, this has been a way that has been pursued in a number of empirical studies as well. ${ }^{25}$

The goodness-of-fit of the model as measured by the R-squared may be not the best criterion for selecting the best model, especially when the model specifications appear similarly good (in terms of the estimated coefficients and standard errors). The estimated

25 There are only a few studies that select the best supply-side specification on the basis of some calculated marginal costs, or some publicly available information on the price-cost margins. For example, Nevo (2001) compares the estimated and observed markups to select the best model specification for the supply side. 
coefficients in different models could be also investigated and assessed to find out which ones are the most plausible ones (e.g., Verboven, 2002, Bonnet et al., 2006).

As mentioned before, models are often selected on the basis of some information criterion (e.g., Akaike (1973, 1974) information criterion (AIC) ${ }^{26}$, Schwarz (1978) Bayesian information criterion (BIC) ${ }^{27}$, Hannan and Quinn (1979)). Under this approach, the model with the smallest information criterion is preferred. However, the selection procedures that these tests are based upon are not completely satisfactory (Rivers and Vuong, 1999). The actual values of the model selection criteria can be subject to statistical variations as they are determined by sample information. The models may not, thus, outperform each other significantly. In case of linear regression models, the criteria that are based on the calculation of the in-sample mean square error of prediction (MSEP) are widespread.

As there appears to be no single most reliable way to choose the best supply-side model, the results from the tests for non-nested hypotheses (MacKinnon, White, and Davidson, 1983, and Rivers and Vuong, 2002), the Akaike information criterion (AIC), the Bayesian information criterion (BIC) and the sum of squared residuals (SSR) are compared in this paper to reach some meaningful and hopefully reliable results at the end. The application of MacKinnon, White, and Davidson (1983), and Rivers and Vuong (2002) test procedures is described in detail in Appendix. The intuition behind these tests is given in the Introduction of the paper. These methods are the most frequently applied in the literature to choose a model specification that best fits the data. In addition, the concrete tests are chosen so that to fit my estimation methods for the supply side.

\subsection{Test for the mutual forbearance hypothesis (2): testing shock effects}

This test could be viewed as continuation of the previous test, or it can be conducted separately as well. The test procedure involves two steps.

Step 1. Estimate the demand and marginal cost equations, and identify the competition behaviour in market segments through testing different assumptions about the firm behaviour (e.g., one market is collusive, the others are not, or all are collusive, etc.), and choose, as above, the best supply-side model, which best fits the data, on the basis of some goodness-offit criteria, or test.

Step 2. Simulate some shock ${ }^{28}$ in a particular market segment, e.g., a price war in the (more) collusive segment, and see whether and to what extent it impacts the firm behaviour in the other market segments. The price war is approximated by the changes in the ownership matrix for that market (from the collusive to the competitive assumption). The question is whether the price war in this particular market segment will have some impact on the firm behaviour in the other market segments. The main idea behind this is to look at the relative magnitude of the "own"-market reactions vs. cross-market reactions, and to see whether there is any correlation in the prices across the market segments. Another alternative is to move from the competitive to the collusive behaviour assumption in a particular market segment.

Consequently, the new equilibrium price under the new ownership matrix $\left(\Omega_{\text {new }}\right)$ is:

\footnotetext{
26 Akaike's information criterion (AIC), based on the minimization of the loss of information, is calculated on the basis of the mean squared prediction error (in case of the OLS estimation).

27 Bayesian Information Criterion (BIC) is similar to the AIC criterion, it imposes only a heavier penalty for the degrees of freedom loss.

28 The examples of possible real shocks could be a significant change in the market share of a firm, or some abrupt change in the multimarket contact measure over time, or a price war in a particular market segment. The relatively short period of time for which I have the data does not allow me to observe such changes in reality, that is why, I chose to simulate some hypothetical shocks.
} 
$p^{*}=\bar{c}+\Omega_{\text {new }}\left(p^{*}\right)^{-1} s\left(p^{*}\right)$

where $p^{*}$ is a vector of the post-predicted equilibrium prices, $\bar{c}$ are the estimated marginal costs from the step-by-step estimation. The system of the non-linear equations has to be solved for an equilibrium price. ${ }^{29}$ The simulation of shocks could probably help me to disentangle the effect of market concentration and multimarket contact on the firm behaviour. In addition, the simulation of shocks to separate markets allows studying the firms' (strategic and collusive) interdependence across the markets.

\section{Data and estimation results}

\subsection{Data}

The major source of the automotive data for this research is the Automotive News Market Data Book for 2001-2003. ${ }^{30}$ The available data for the US automotive market include:

1. Car and light truck sales by market class for models. In the dataset those models with the yearly sales of less than 200 models have been excluded.

2. Prices of cars, pickups, minivans, vans and SUVs.

Prices for the given year are shown as of April/May of the corresponding year. The base prices include the retail price as suggested by the manufacturer and the destination charge. The prices of imported vehicles cover ocean freight and the U.S. import duty. State, or local taxes, or optional equipment are not included into the prices. The list prices are converted into real terms by using the US Consumer Price Index (CPI).

3. Vehicles characteristics: auto transmission, air conditioning, antilock brakes, sunroof/moonroof; information on dimensions, engines, capacities, safety, miscellaneous. The physical characteristics of the base specification have been used in the estimations.

4. Automotive advertising spending in the US (measured by the US ad spending per vehicle).

The data on miles per gallon, engine volume, cylinders are available from the Fuel Economy Guide by the US Environmental Protection Agency (EPA)). The log of the total sales volume, or global production by model, which is available from the Global Insight, can be used to account for the economies of scale. The GDP data are taken from the Bureau of Economic Analysis (BEA)).

The number of potential customers is approximated by the total number of households in the economy, following Berry, Levinsonhn and Pakes (1995). Each household is treated to be a potential buyer of a new car. The information on the number of households is taken from the US Census Bureau.

The automotive market classification by the Automotive News, which is used in this study, is determined by vehicle size, price and market intent. ${ }^{31}$ The cars are segmented into the

29

30

31

Nevo (1997) solves $\Omega_{\text {post }}(p *)(p *-\widehat{m} c)=s(p *)$ using Matlab standard algorithm for solving nonlinear equations (fsolve.m).

I have tried to do some cross-sectional estimations, but it is difficult to fit the model. This result is similar to the one by Berry, Levinsohn and Pakes (1995), who have chosen to use the panel data, and Nevo (2001), who has used the quarterly data for several geographical markets.

For the sensitivity analysis (for my estimations, the definition of a relevant market is very important), alternative market segmentations could be tried, in particular, the one by Ward (Ward's Automotive Yearbook). According to this classification, which is based upon price, body style and size, the light vehicles are segmented into the following classes: small, middle, large, luxury, cross-utility vehicles, SUVs, vans and pickups. 
following classes: small, midrange, traditional, upscale, sporty, alternative power ${ }^{32}$. The light trucks are segmented into the following classes: pickups, vans, and SUVs. SUVs, midrange, and pickups are the largest car market segments in the US. The SUVs market is characterized by the highest number of car models and may be viewed as the most competitive one. Japanese competitors play a large role in the smaller car market segments, while the European car producers are the major competitors of the US car producers in the upscale market segment.

The summary statistics for selected variables across the market segments are presented in Table 5. The prices, size and horsepower increase as one moves from the smaller car segments to the larger ones, also to those with the higher presence of premium car brands.

Table 5: US light vehicles market: descriptive statistics across market segments

\begin{tabular}{|c|c|c|c|c|}
\hline \multirow[t]{2}{*}{ Variable } & \multirow[t]{2}{*}{ Mean } & \multicolumn{3}{|l|}{ Std. dev. } \\
\hline & & Overall & Between & Within \\
\hline \multicolumn{5}{|l|}{ Small } \\
\hline horsepower & 122 & 14.9 & 14.1 & 5.3 \\
\hline price & 12968 & 1608.5 & 1620.4 & 231.8 \\
\hline size & 11795 & 622.7 & 595.4 & 166.0 \\
\hline \multicolumn{5}{|l|}{ Midrange } \\
\hline horsepower & 159 & 25.9 & 25.5 & 5.3 \\
\hline price & 18949 & 2703.0 & 2673.3 & 402.1 \\
\hline size & 13262 & 1038.6 & 1007.3 & 264.5 \\
\hline \multicolumn{5}{|l|}{ Traditional } \\
\hline horsepower & 215 & 15.4 & 18.1 & 1.1 \\
\hline price & 25064 & 1810.0 & 2050.2 & 351.1 \\
\hline size & 15366.7 & 980.2 & 1006.9 & 27.3 \\
\hline \multicolumn{5}{|l|}{ Upscale } \\
\hline horsepower & 227 & 38.1 & 37.8 & 6.1 \\
\hline price & 38009 & 10951.9 & 11009.7 & 845.8 \\
\hline size & 13917 & 1186.3 & 1165.6 & 251.7 \\
\hline \multicolumn{5}{|l|}{ Sporty } \\
\hline horsepower & 199 & 61.7 & 61.8 & 3.9 \\
\hline price & 29822.1 & 15889.1 & 15591.9 & 390.0 \\
\hline size & 11956 & 1245 & 1235.7 & 169.4 \\
\hline \multicolumn{5}{|l|}{ Pickup } \\
\hline horsepower & 164 & 35.8 & 35.0 & 11.6 \\
\hline price & 15570 & 2368.2 & 2369.1 & 588.6 \\
\hline size & 14527 & 1648.4 & 1686.2 & 227.2 \\
\hline \multicolumn{5}{|l|}{ Van } \\
\hline horsepower & 188 & 19.3 & 17.5 & 8.2 \\
\hline price & 22668 & 2109.9 & 2015.7 & 544.3 \\
\hline size & 15135 & 1180.0 & 1153.8 & 153.4 \\
\hline \multicolumn{5}{|l|}{ SUV } \\
\hline horsepower & 202 & 54.0 & 52.7 & 10.3 \\
\hline price & 25386.9 & 7012.2 & 6910.2 & 1020.8 \\
\hline size & 13543 & 1794.7 & 1808.4 & 24.9 \\
\hline
\end{tabular}

Source: Automotive News Market Data Book, own calculations

32 The alternative power market is not analyzed because it is a thin market. 
In my estimations I do not include all the available technical characteristics in order to minimize the problem of multicollinearity. The variables have been chosen into the specification on the basis of the p-value correlation analysis. The summary of the variables used in the estimations is given in Table 6. The following variables have been selected into the specifications: horsepower (to measure car performance), width and length (vehicle dimensions), air conditioning and antilock brakes (safety), automatic transmission (convenience), miles per gallon (MPG) (fuel efficiency).

Table 6: US light vehicles market: variables description

\begin{tabular}{l|ll}
\hline \hline Variable & Variable name & Notes \\
\hline Horsepower & horse & Net horsepower \\
Width & width & Overall width (in.) \\
Length & length & Overall length (in.) \\
Air conditioning & air-cond & Dummy: 1 if air conditioning \\
& brakes & is standard equipment \\
Antilock brakes & Dummy: 1 if antilock brakes & is standard equipment \\
Transmission & transm & Dummy: 1 if automatic \\
& & transmission is standard \\
& equipment & City miles per gallon: for \\
Miles-per-gallon & urban driving \\
\hline \hline
\end{tabular}

Source: Automotive News Market Data Book, own calculations

\subsection{Estimation strategies for the demand equation and full system}

In general, the demand and pricing equations can be estimated either separately, or jointly. Under the separate, or step-by-step, estimation, the demand equation is estimated first. After that the matrix of own- and cross-price elasticities is constructed on the basis of the estimated demand parameters. In the next step the pricing equation is estimated after having substituted into it the matrix of the elasticities. The standard errors of the pricing equation parameters have to be corrected.

There are several advantages of this two-step procedure. For example, the computational burden may be reduced due to the separate estimation of the demand and pricing equations. Different supply-side specifications may be estimated without re-estimating the demand function each time. The possible misspecification of the supply side will have no impact on the demand side results (Goldberg and Verboven, 2001). ${ }^{33}$ The major drawback of this procedure is the loss in the efficiency of the estimated parameters.

\subsection{Instruments}

Prices and market shares are endogenous, correlated with the error term $\xi_{j}$ and $\omega_{j}$, and, consequently, have to be instrumented. Prices will be collinear with product characteristics that are not observed. The introduction of product fixed effects to control for unobserved characteristics can lead to an identification problem due to the correlation between fixed effects and product characteristics. If there is some positive correlation between prices and omitted characteristics, the price coefficient will tend towards zero.

The detailed discussion of the choice of the efficient instruments for differentiated products models can be found in Berry, Levinsohn and Pakes (1995). In general several groups of

33 Step-by-step estimations are also used by Nevo (2001). 
instruments can be pointed out that have been used in the studies on the differentiated products demand and structural model estimation: cost shifters and quasi-cost shifters, product characteristics, prices in other markets (following Hausman et al. (1994) and Hausman (1996)), etc. ${ }^{34}$ I use the product characteristics as instruments in my estimations, which I will discuss in detail in the following.

The best candidates for the instruments in the differentiated product markets are the model characteristics, which are usually treated as exogenous, based on the assumption that in the short run they cannot be quickly adjusted by a firm. Thus, the matrix $Z$ of instruments includes the product's own characteristics (which decreases the number of necessary additional instruments) and other exogenous variables used in the estimations. Product characteristics are used as instruments for a set of unobserved supply shifters in the pricing, or marginal cost equation. Furthermore, the functions of the exogenous characteristics of the competing products can be used as instruments.

The major difficulty with using nonprice characteristics as instruments is that these variables are usually used both in the demand and cost side. As a result, there may be an insufficient number of instruments for the parameters that have to be estimated. This problem has been discussed by Berry (1994) and Berry, Levinsohn and Pakes (1995), and the usage of the characteristics of competitors and their functions as additional instruments has been suggested. The functions of the exogenous physical characteristics (own and competitors') can be used as instruments (sums and averages). The car's own price and demand will be correlated with the physical characteristics of the other products, and depend on the degree and closeness of competition that the firms face with other competitors. The distance from the nearest neighbouring product will determine the markup of each brand.

Bresnahan et al. (1997) suggest the following groups of instruments: principles of differentiation (defined on a group-specific basis), ownership (defined on a firm-specific basis, making use of the economics of the multiproduct pricing) and ownership with principles of differentiation (combination of a group-specific and a firm-specific basis).

Therefore, the following instruments could be used for the estimation of the one-level nested logit: 1) number of other products in a group; 2) sum/average of characteristics of other products in a group (interacted with a group dummy variable); 3) number of other products the firm sells in the group; 4) sum/average of characteristics of other products the firm sells in the group (interacted with a group dummy variable); 5) number of products the other firms sell in the group; 6) sum/average of characteristics of products the other firms sell in the group (interacted with a group dummy variable).

34 Other authors use a lagged error term in the demand equation (Bonnet et al., 2005), brand dummies (Nevo, 2001), or lagged endogenous variables as instruments. 


\subsection{Estimation results}

\subsubsection{Demand and supply}

The results of the demand estimation for the one-level nested logit ${ }^{35}$ can be found in Table 7 . The demand equation can be estimated by the 2SLS, or GMM. The null hypothesis of homoscedasticity has been tested by performing the test of heterogeneity by Pagan and Hall (1983) for the instrumental variables estimation. The test results have not rejected the homoscedasticity hypothesis, thus, the IV estimation should be rather used (see the first two columns in Table 7). GMM estimation results are presented for sensitivity analysis and are quite similar in magnitude to the 2SLS estimation results (see the last two columns in Table 7).

Table 7: US light vehicles market: demand estimation

\begin{tabular}{lllll}
\hline \hline Variables & $I V . A$ & $I V . B$ & $G M M . A$ & $G M M . B$ \\
\hline$\alpha$ & $-0.00015^{* * *}$ & $-4.00^{* * *}$ & $-0.00017^{* * *}$ & $-4.47^{* * *}$ \\
$\sigma(g)$ & $0.87^{* *}$ & $0.70^{* *}$ & $0.80^{* * *}$ & $0.69^{* *}$ \\
horsepower & $0.02^{* * *}$ & $0.01^{* * *}$ & $0.02^{* * *}$ & $0.02^{* * *}$ \\
width & $-0.06^{* *}$ & -0.03 & $-0.05^{* *}$ & $-0.03^{*}$ \\
length & -0.01 & -0.002 & -0.003 & -0.005 \\
air conditioning & 0.08 & $0.49^{* * *}$ & $0.18^{*}$ & $0.55^{* * *}$ \\
brakes & 0.16 & $0.29^{* *}$ & $0.21^{*}$ & $0.36^{* * *}$ \\
transmission & $0.39^{* * *}$ & $0.34^{* * *}$ & $0.38^{* *}$ & $0.43^{* * *}$ \\
mpgcity & $-0.04^{*}$ & $-0.07^{* * *}$ & $-0.03^{*}$ & $-0.08^{* * *}$ \\
const & 0.63 & $35.19^{* * *}$ & -0.39 & $40.16^{* * *}$ \\
\hline Adj. R2 & 0.36 & 0.56 & 0.26 & 0.51 \\
Root MSE & 1.06 & 0.88 & 1.14 & 0.93 \\
Pagan\&Hall & 1.00 & 0.99 & - & - \\
(all, p-value) & & & & 3.14 \\
Overidentification & & & 4.95 & \\
\hline \hline
\end{tabular}

Source: own estimations

Note: Specifications IV.A and GMM.A are with prices in levels, while Specifications IV.B and GMM.B are estimated with prices expressed in logarithms. ***, **, * - indicate significance at $1 \%, 5 \%$ and $10 \%$ significance level, respectively. Time dummies have been included but are not reported. mpgcity stands for miles per gallon (city). Nest is market segment.

Horsepower has been found statistically significant in all specifications and has a positive sign as expected. Width and length have got a negative sign. Length is, however, not significant anyway. Air conditioning, brakes and automatic transmission also have got an expected positive sign. The miles per gallon variable has a negative sign contrary to the a priori expectations: the higher miles per gallon value, the more efficient the vehicle is. The negative sign was also found in some other studies (e.g., Berry, Levinsohn and Pakes, 1995, Sudhir, 2001). The included but not reported in the table time fixed effects might capture macro-economic fluctuations that influence a person's decision to buy a car.

35 The estimations with different correlation parameters for different market segments (not reported here) produced rather implausible magnitudes (higher correlation for more luxury segments), and some coefficients turned out to be greater than 1, although the Wald test has not rejected the hypothesis that they could be equal to or less than one. The latter problem could be explained by the choice of instruments. It should be also mentioned that in some cases the coefficients greater than 1 could be consistent with the utility-maximizing behaviour.

Besides I have done estimations for the nested logit with two nests (market segment and country of origin, i.e., domestic vs. foreign producer) and the estimates of the correlation parameters were not consistent with utility-maximizing behaviour. 
For the calculation of own- and cross-price elasticities, the estimation of markups and the subsequent supply-side estimations, the estimates of price and segment correlation parameters are considered to be the most important. The price coefficient is negative as expected and is quite low in magnitude. The estimated segment correlation parameters can be interpreted in terms of the correlation of consumer preferences within a particular market segment. When the correlation parameters are statistically different from zero, this may mean that consumers may not be so willing to substitute away from that market segment when there is a price increase in that segment. The results show that consumer preferences are strongly correlated within a market segment. This may be interpreted as some evidence for strong competition within market segments in the US light vehicles market.

I have also estimated the demand equation jointly with the hedonic pricing equation. These results can be found in Table 8 (first column, 'joint estimation'). In this case width, length, and miles per gallon have got a statistically significant positive sign, however, the air conditioning has got a negative sign. One may argue that adding the supply side contributes to a better model identification. The segment correlation parameter is significantly lower than under the separate estimation of the demand equation.

I also present some results of the random coefficients model estimation for the US light vehicles market (the last four columns, 'random'). ${ }^{36}$ The first two columns give the parameter estimates and their standard errors for the means ( $\beta$ 's), while the last two columns give the parameter estimates and their standard errors of standard deviations $\left(\sigma_{k}\right.$ 's). However, the results of many coefficients have turned out to be negative. ${ }^{37}$ Thus, it could be better to rely on the estimates from the one-level nested logit to proceed with the test for the multimarket contact effects.

36 I have tried to estimate the demand equation, which is derived from the following utility specification following Berry, Levinsohn and Pakes (1999):

$u_{i j}=x_{j} \beta+\xi_{j}-\alpha_{i} p_{j}+\sum_{k} \sigma_{k} x_{j k} v_{i k}+\varepsilon_{i j}$ for $j=1, \ldots, J$, where $\alpha_{i}=\frac{\alpha}{y_{i}}, \beta$ is a vector of mean parameters to be estimated, and $\sigma_{k}$ is a vector of standard deviations parameters to be estimated.

The price coefficient is interacted with income. Income draws are made from the US Consumer Population Survey (CPS). I introduce consumer heterogeneity on the products characteristics: the random draws have been made from multinominal normal distribution $\left(v_{i k}\right)$. This together should have allowed

me to get more flexible substitution patterns.

One of the possible explanations could be the short time period of the data that I have. A longer time span, and, thus, a larger number of markets could contribute to the better model identification. 
Table 8: US light vehicles market: demand estimation (continuation)

\begin{tabular}{|c|c|c|c|c|c|}
\hline \multirow[t]{3}{*}{ Variables } & \multirow{3}{*}{$\begin{array}{l}\text { Joint } \\
\text { estimation }\end{array}$} & \multicolumn{4}{|l|}{ Random } \\
\hline & & \multicolumn{2}{|c|}{ Means $\left(\beta^{\prime} s\right)$} & \multicolumn{2}{|l|}{$\begin{array}{l}\text { Std. } \\
\text { deviations } \\
(\sigma(k) \text { 's) }\end{array}$} \\
\hline & & Estimate & Std. err. & Estimate & Std. err. \\
\hline price-income & $-0.0001^{* * *}$ & -4.30 & 0.00 & & \\
\hline $\begin{array}{l}\text { ln } \\
\text { (segmentshare) }\end{array}$ & $0.43^{* * *}$ & & & & \\
\hline horsepower & $0.01 * * *$ & 0.60 & 0.01 & 0.06 & 0.04 \\
\hline width & $0.11^{* * *}$ & -1.14 & 0.03 & 0.13 & 0.26 \\
\hline length & $0.01 * * *$ & 2.37 & 0.02 & 0.08 & 0.11 \\
\hline $\begin{array}{l}\text { air } \\
\text { conditioning }\end{array}$ & $-0.23 * * *$ & -0.18 & 0.00 & 0.12 & 0.05 \\
\hline brakes & $1.17 * * *$ & -0.15 & 0.01 & 0.03 & 0.05 \\
\hline transmission & $0.97 * * *$ & -0.05 & 0.04 & 0.08 & 0.10 \\
\hline mpgcity & $0.13^{* * *}$ & -3.49 & 0.07 & 0.16 & 0.00 \\
\hline year01 & & 0.28 & 0.00 & & \\
\hline year02 & & 0.39 & 0.01 & & \\
\hline const & $-17.38 * * *$ & -9.83 & 0.12 & 0.24 & 0.05 \\
\hline
\end{tabular}

Source: own estimations

Note: $* * *, * *, *$ indicate significance at $1 \%, 5 \%$ and $10 \%$ levels of significance, respectively. Time dummies have been included but are not reported in case of joint estimation.

The supply-side equation under different assumptions on the firms' equilibrium interactions is estimated using OLS with robust standard errors (Huber/White sandwich estimator of the variance) (see Table 9). ${ }^{38}$ This table presents the results for some selected specifications: 'Single': single-product Bertrand pricing equilibrium; 'Multi': multi-product (brand-level) Bertrand pricing equilibrium; 'Market': market-segment collusive assumption for each market segment; 'Hedonic': the pricing equation under a competitive assumption; MMC1: collusive assumption for GM, Ford, DaimlerChrysler, Toyota and Renault-Nissan and competitive assumption for the others; MMC2: collusive assumption for GM, Ford, DaimlerChrysler, Toyota, Honda, Hyundai and BMW and competitive assumption for the others; MMC3: collusive assumption for GM, Ford, DaimlerChrysler and Toyota and competitive assumption for the others; MMC4: collusive assumption for GM, Ford, DaimlerChrysler and competitive assumption for the others.

Horsepower is found to be positive in all specifications. The signs and magnitudes of some coefficients have been changing across different specifications. ${ }^{39}$ Initially Toyota doesn't appear to be the most efficient producer. These results may be in line with some of the results of the previous studies. In particular, Petrin (2002) finds the marginal costs to be slightly higher for Japanese producers as compared to those of American producers. Higher marginal costs for Japanese producers have been also found by Sudhir (2001).

\footnotetext{
$38 \quad$ I present the estimation results under selected assumptions, as the results are rather similar under all specifications, just to illustrate the problem that I have faced while choosing the best supply-side specification: on the basis of the estimated coefficients and R-squared comparison the supply-side models do not appear to outperform each other significantly. equations. Therefore, they performed a non-nested test to differentiate between different patterns of competition.
} 
Table 9: US light vehicles market: supply-side estimation results under selected assumptions

\begin{tabular}{|c|c|c|c|c|c|c|c|c|}
\hline Variables & Single & Multi & Market & Hedonic & $M M C 1$ & $M M C 2$ & $M M C 3$ & $M M C 4$ \\
\hline horsepower & $1.00 * * *$ & $1.01 * * *$ & $1.26 * * *$ & $0.95 * * *$ & $1.18 * * *$ & $1.20 * * *$ & $1.13 * * *$ & $1.07 * * *$ \\
\hline width & -0.05 & -0.05 & 0.16 & -0.05 & 0.14 & 0.01 & 0.02 & -0.13 \\
\hline length & $-0.50 * * *$ & $-0.50 * * *$ & $-0.74 * * *$ & $-0.48 * * *$ & $-0.94 * * *$ & $-0.64 * * *$ & $-0.79 * * *$ & $-0.52 * * *$ \\
\hline air conditioning & $0.16 * * *$ & $0.16 * * *$ & $0.28 * * *$ & $0.14^{* * *}$ & $0.24 * * *$ & $0.24 * * *$ & $0.22 * * *$ & $0.17 * * *$ \\
\hline brakes & $0.07 * * *$ & $0.07 * * *$ & $0.08 * * *$ & $0.06 * * *$ & $0.05^{*}$ & $0.06 * * *$ & $0.05 * *$ & $0.04 * *$ \\
\hline transmission & $0.14 * * *$ & $0.14 * * *$ & $0.16 * * *$ & $0.13 * * *$ & $0.20 * * *$ & $0.15 * * *$ & $0.18 * * *$ & $0.19 * * *$ \\
\hline mpgcity & 0.00 & 0.01 & -0.09 & 0.02 & $0.19 * * *$ & $0.12 *$ & $0.16^{* *}$ & $0.10^{*}$ \\
\hline year01 & $0.03 * *$ & $0.03 * *$ & $0.04 * *$ & $0.03 * *$ & $0.03 *$ & $0.04 * *$ & $0.03 *$ & $0.03 *$ \\
\hline year02 & 0.02 & 0.02 & 0.03 & 0.02 & 0.02 & 0.03 & 0.02 & 0.02 \\
\hline hyundai & $-0.37 * * *$ & $-0.38 * * *$ & $-0.60 * * *$ & $-0.34 * * *$ & $-0.22 * * *$ & $-0.50 * * *$ & $0.21 * * *$ & $-0.23^{* * *}$ \\
\hline kia & $-0.36 * * *$ & $-0.37 * * *$ & $-0.60 * * *$ & $-0.33 * * *$ & $-0.16 * * *$ & $-0.52 * * *$ & $-0.17 * * *$ & $-0.20 * * *$ \\
\hline toyota & $-0.21 * * *$ & $-0.22 * * *$ & $-0.33 * * *$ & $-0.19 * * *$ & $-0.33 * * *$ & $-0.31 * * *$ & $-0.30 * * *$ & $-0.10 * * *$ \\
\hline gm & $-0.32 * * *$ & $-0.34 * * *$ & $-0.47 * * *$ & $-0.30 * * *$ & $-0.41 * * *$ & $-0.41 * * *$ & $-0.38 * * *$ & $-0.34 * * *$ \\
\hline ford & $-0.27 * * *$ & $-0.29 * * *$ & $-0.40 * * *$ & $-0.25 * * *$ & $-0.36 * * *$ & $-0.36 * * *$ & $-0.33 * * *$ & $-0.29 * * *$ \\
\hline chrysler & $-0.30 * * *$ & $-0.31 * * *$ & $-0.43 * * *$ & $-0.28 * * *$ & $-0.40 * * *$ & $-0.39 * * *$ & $-0.38 * * *$ & $-0.34 * * *$ \\
\hline nissan & $-0.40 * * *$ & $-0.41 * * *$ & $-0.57 * * *$ & $-0.38 * * *$ & $-0.52 * * *$ & $-0.22 * * *$ & $-0.27 * * *$ & $-0.28 * * *$ \\
\hline mazda & $-0.17 * * *$ & $-0.17 * * *$ & $-0.26 * * *$ & $-0.15 * * *$ & $-0.25 * * *$ & $-0.24 * * *$ & $-0.22 * * *$ & $-0.19 * * *$ \\
\hline mitsubishi & $-0.21 * * *$ & $-0.22 * * *$ & $-0.33 * * *$ & $-0.19 * * *$ & -0.08 & 0.02 & -0.07 & $-0.09 *$ \\
\hline suzuki & $-0.40 * * *$ & $-0.41 * * *$ & $-0.59 * * *$ & $-0.37 * * *$ & $-0.55 * * *$ & $-0.57 * * *$ & $-0.51 * * *$ & $-0.44 * * *$ \\
\hline honda & $-0.24 * * *$ & $-0.26 * * *$ & $-0.35 * * *$ & $-0.23 * * *$ & $-0.17 * * *$ & $-0.31 * * *$ & $-0.15 * * *$ & $-0.14^{* * *}$ \\
\hline vw & $-0.12 * * *$ & $-0.13 * * *$ & $-0.21 * * *$ & $-0.11 * * *$ & 0.02 & 0.09* & 0.02 & 0.02 \\
\hline subaru & $-0.27 * * *$ & $-0.28 * * *$ & $-0.40 * * *$ & $-0.25 * * *$ & $-0.14 * * *$ & $-0.10 * *$ & $-0.14 * * *$ & $-0.14 * * *$ \\
\hline audi & -0.05 & -0.06 & $-0.12 * *$ & -0.04 & -0.00 & 0.07 & 0.02 & 0.05 \\
\hline bmw & 0.04 & 0.02 & -0.03 & 0.04 & 0.10 & 0.00 & $0.21 * *$ & $0.13 * * *$ \\
\hline mercedes & $0.22 * * *$ & $0.21^{* * *}$ & $0.17 * * *$ & $0.22 * * *$ & $0.18 * * *$ & $0.20 * * *$ & $0.21^{* * *}$ & $0.24 * * *$ \\
\hline volvo & $0.07^{*}$ & 0.06 & 0.03 & $0.07 *$ & 0.05 & 0.02 & 0.07 & $0.09 * *$ \\
\hline jaguar & 0.08* & 0.07 & 0.00 & $0.09 * *$ & 0.04 & 0.03 & 0.07 & $0.11^{* *}$ \\
\hline saab & $0.20 * * *$ & $0.19 * * *$ & $0.20 * * *$ & $0.19 * * *$ & $0.20 * * *$ & $0.16 * * *$ & $0.21 * * *$ & $0.22 * * *$ \\
\hline const & $7.58 * * *$ & $7.49 * * *$ & $6.58 * * *$ & $7.61 * * *$ & $7.42 * * *$ & $6.47 * * *$ & $7.57 * * *$ & $7.30 * * *$ \\
\hline R-sqr. & 0.89 & 0.89 & 0.90 & 0.89 & 0.87 & 0.88 & 0.87 & 0.89 \\
\hline Root MSE & 0.14 & 0.14 & 0.18 & 0.13 & 0.18 & 0.17 & 0.17 & 0.15 \\
\hline
\end{tabular}

Source: own estimations

Note: $* * *, * * *$ - indicate significance at $1 \%, 5 \%$ and $10 \%$ significance level, respectively. The estimates are presented based on GMM.A specification. Isuzu is used as a reference group. Horsepower, width, length and mpgcity (miles per gallon, city) are in logarithmic form. 


\subsubsection{Results of the test for the mutual forbearance hypothesis}

\section{Testing collusive assumption among multimarket contact firms}

The application of the test for the mutual forbearance hypothesis for the automotive industry as described above is complicated by the high concentration ratios and the fact that the automotive manufacturers are present in almost every market segment. Thus, one needs to find some variation in the multimarket contact among the automotive firms in the US car market in order to reduce the number of potential candidates for the multimarket contact firms. This could form the "multimarket contact firms coalition" for which the assumption of implicit collusive behaviour could be then tested. There could be different criteria for that, for example, how long the firm has been present in the market, difference due to the geographical market presence, technology difference (e.g., diesel technology), number of markets in which a firm is present, etc.

In the US, the firms that are present in all automotive product markets are Toyota, GM, Ford and DaimlerChrysler. The Renault-Nissan group is present in all the markets, except for the traditional market segment.

The criteria that I use for the differentiation of the multimarket contact to point out the coalitions of multimarket contact firms are: 1) the presence of the firm in all or almost all market segments, 2) multimarket firms with shares with more than $10 \%$ in each market segment (i.e., considering "influential" rivals, with "spheres of influence"), and 3) the combination of the above two criteria. Under the first criterion the collusion possibility between GM, Ford, DaimlerChrysler, Toyota and Renault-Nissan groups is tested. Under the second criterion, there is a collusion possibility between GM, Ford, DaimlerChrysler, Toyota, Honda, Hyundai and BMW. Under the third criterion, the collusion is tested between GM, Ford, DaimlerChrysler and Toyota. The collusive (cooperative) assumption between GM, Ford, DaimlerChrysler and Toyota should be also tested on the basis of the fact that they are present in all market segments and have the highest number of multiple contacts. In addition, the collusive behaviour between GM, Ford, and DaimlerChrysler is tested as these firms have dominated the US automotive market in general and across separate market segments. In addition, Toyota has been argued to be the "heatest" competitor for the US car producers, so cooperative behaviour between them could be rather doubtful. For the other firms, I have tested different assumptions: competitive, single-product, or multi-product.

The choice of the above criteria for the multimarket contact differentiation has been based on the following arguments. Not only the diversification aspect matters (to support collusion due to multimarket contact it is not enough to be present in several markets) but also the ability of the firms to use it in the creation of the transferrable slack should be taken into account. It is unlikely that the firms with a small market share will be able to generate the necessary slack (which is usually fostered by the market concentration), which could be transferred to the other markets through the multimarket contact.

As I have mentioned above, in my estimations I distinguish between multi-product (brand) and multi-product (manufacturer group, taking into account the cross-shares in other firms) assumptions. Under the latter assumption, a joint profit maximization for Hyundai and Kia; GM, Suzuki, Saab and Isuzu; Ford, Mazda, Volvo and Jaguar; Chrysler, Mitsubishi and Mercedes; and VW and Audi is assumed, but this led to only slight changes in the markups as compared to those under the multi-product (brand) assumption. This is attributed to the low market shares of the car brands that are added to the main (parent) brand and the low crossprice elasticities of demand.

In accordance with the above assumptions, the ownership matrix $\theta$ is adjusted, and the markups could be calculated on the basis of the demand estimates from the first step. Given 
the markups, the marginal costs under different assumptions could be calculated (see Section 4.2.1 for more detail).

The results of the estimated marginal costs equations under selected multimarket contact assumptions can be found in Table 9 above. For the best supply-side model selection, the best way would be, of course, to get the real estimates of the marginal costs of the automotive firms at the model level, and to compare the obtained estimates with those. However this is difficult to realize in practice. Not surprisingly, there is not so much publicly available information about the margins of the OEMs in the US car market.

That is why, I move on to the discussion of the results from several statistical procedures (in order to conduct robustness checks) to choose the most-preferred supply-side specification that best fits the data. Relying on the "goodness-of-fit" of the model may be not the best criterion for selecting the best model under these circumstances. As it can be already seen from the estimation results (see Table 9), the R-squared is rather similar for all model specifications. Below I apply the information criteria (Akaike (AIC), and Bayesian (BIC)), sum of squared residuals (SSR), the test for non-nested hypotheses by MacKinnon, White and Davidson (1983), and the test for model selection by Rivers and Vuong (2002) to try to choose the model that best fits the data.

The results of the comparison of the information criteria and the sum of squared residuals (SSR) as a way to differentiate between the supply side models can be found in Table 10. In addition to the single-product, multi-product (brand), multi-product (group) and market segment collusion assumptions, the information criteria for the following multimarket contact firms coalitions have been estimated: MMC1: collusive assumption for GM, Ford, DaimlerChrysler, Toyota and Renault-Nissan and competitive assumption for the others; MMC2: collusive assumption for GM, Ford, DaimlerChrysler, Toyota, Honda, Hyundai and BMW and competitive assumption for the others; MMC3: collusive assumption for GM, Ford, DaimlerChrysler and Toyota and competitive assumption for the others; MMC4: collusive assumption for GM, Ford, DaimlerChrysler and competitive assumption for the others; MMC5: collusive assumption for GM, Ford, DaimlerChrysler, Toyota and RenaultNissan and single-product assumption for the others; MMC6: collusive assumption for GM, Ford, DaimlerChrysler, Toyota and Renault-Nissan and multi-product assumption for the others; MMC7: collusive assumption for GM, Ford, DaimlerChrysler, Toyota, Honda, Hyundai and BMW and single-product assumption for the others; MMC8: collusive assumption for GM, Ford, DaimlerChrysler, Toyota, Honda, Hyundai and BMW and multiproduct assumption for the others; MMC9: collusive assumption for GM, Ford, DaimlerChrysler and Toyota and single-product assumption for the others; MMC10: collusive assumption for GM, Ford, DaimlerChrysler and Toyota and multi-product assumption for the others; MMC11: collusive assumption for GM, Ford, DaimlerChrysler and single-product assumption for the others; MMC12: collusive assumption for GM, Ford, DaimlerChrysler and multi-product assumption for the others.

The model specification that gets the lowest information criteria and SSR should be chosen as the supply-side specification that best fits the data. The specifications of the single-product, multi-product (brand) and multi-product (manufacturer group) price competition have got the lowest Akaike Information Criterion (AIC) and Bayesian Information Criterion (BIC) values. However, these values are not that different from the values for the supply-side specification under the three multimarket contact assumptions, namely collusive behaviour for Ford, GM and DaimlerChrysler and competitive (MMC4), or single-product (MMC11), or multiproduct (MMC12) price competition for the other automotive players. That is why one should be rather careful in making conclusions on the basis of these information criteria results. The comparison of the SSR values shows a similar picture. It should be noted that the SSR in any case could not be treated as a sufficient condition for rejecting all the other null hypotheses. 
Table 10: US light vehicles market: information criteria and sum of squared residuals (SSR) for different supply side specifications

\begin{tabular}{llll}
\hline \hline Specifications & AIC & BIC & SSR \\
\hline Single-product & -539.63 & -415.83 & 9.97 \\
Multi-product (brand) & -535.29 & -411.49 & 10.05 \\
Multi-product (group) & -534.40 & -410.59 & 10.07 \\
Market segment collusion & -306.90 & -183.10 & 15.49 \\
MMC1 & -306.30 & -182.50 & 15.51 \\
MMC2 & -324.57 & -200.76 & 14.98 \\
MMC3 & -345.43 & -221.63 & 14.40 \\
MMC4 & -497.40 & -373.60 & 10.80 \\
MMC5 & -306.56 & -182.76 & 15.50 \\
MMC6 & -306.77 & -182.96 & 15.49 \\
MMC7 & -331.26 & -207.45 & 14.79 \\
MMC8 & -331.34 & -207.54 & 14.79 \\
MMC9 & -347.72 & -223.91 & 14.34 \\
MMC10 & -347.81 & -224.00 & 14.33 \\
MMC11 & -480.08 & -356.28 & 11.16 \\
MMC12 & -478.98 & -355.18 & 11.18 \\
\hline \hline
\end{tabular}

Source: own estimations

Note: ,AIC' means Akaike Information Criterion, ,BIC’ stands for Bayesian Information Criterion, and ,SSR' denotes sum of squared residuals.

The results of the test for nonnested hypotheses by MacKinnon, White and Davidson (1983) can be found in Table 11. The detailed description of the test procedure that I have applied can be found in Appendix. At the top of each row there are several modes of market conduct (null hypothesis). Each of the columns represents one of the alternative market conduct scenarios (alternative hypothesis). The results of the test can be best seen by evaluating the columns. It could be seen that when the alternative is MMC4 assumption (specification A8), i.e., collusive assumption for the American Big Three GM, Ford and DaimlerChrysler and competitive assumption for all other automotive players, all other null hypotheses are rejected. That is, this supply-side specification could be arguably the most preferred supply-side specification on the basis of this test. 
Table 11: US light vehicles market: results of the test for the non-nested hypotheses (MacKinnon, White and Davidson, 1983)

\begin{tabular}{|c|c|c|c|c|c|c|c|c|c|c|c|c|c|c|c|c|}
\hline $\mathrm{HO} / \mathrm{HI}$ & $A 1$ & $A 2$ & $A 3$ & $A 4$ & $A 5$ & $A 6$ & $A 7$ & $A 8$ & $A 9$ & $A 10$ & A11 & $A 12$ & $A 13$ & A14 & $A 15$ & A16 \\
\hline A1 & & -0.0 & 0.6 & 1.7 & -6.0 & -0.5 & -5.3 & -2.6 & -6.1 & -6.1 & -0.5 & -0.5 & -5.4 & -5.3 & -2.8 & -2.7 \\
\hline A3 & 0.1 & -1.1 & & 1.4 & -6.4 & -0.6 & -5.6 & -3.0 & -6.4 & -6.4 & -0.6 & -0.6 & -5.7 & -5.6 & -3.2 & -3.1 \\
\hline A5 & 14.8 & 14.9 & 15.0 & 14.7 & & 11.2 & 6.2 & 14.4 & -0.9 & 0.8 & 11.1 & 11.1 & 1.8 & 1.8 & 8.9 & 8.9 \\
\hline A6 & 5.8 & 5.7 & 5.8 & 6.0 & -5.2 & & -4.9 & 2.0 & -5.3 & -5.3 & 0.0 & -0.0 & -5.0 & -5.0 & 1.8 & 1.9 \\
\hline A7 & 13.0 & 13.0 & 13.1 & 12.8 & -2.3 & 9.5 & & 12.2 & -2.3 & -2.2 & 9.5 & 9.5 & -1.1 & 0.5 & 12.1 & 12.1 \\
\hline A8 & 7.2 & 7.3 & 7.4 & 7.3 & -8.0 & 2.0 & -7.5 & & -8.0 & -8.0 & 2.0 & 2.0 & -7.6 & -7.5 & -3.7 & -1.3 \\
\hline A10 & 14.8 & 14.9 & 15.0 & 14.7 & -0.2 & 11.3 & 6.1 & 14.3 & -1.3 & & 11.3 & 11.3 & 6.0 & 6.1 & 14.1 & 14.2 \\
\hline A11 & 5.9 & 5.8 & 5.8 & 6.1 & -5.2 & 0.1 & -4.9 & 2.0 & -5.3 & -5.3 & & -0.1 & -4.9 & -4.9 & 1.9 & 1.9 \\
\hline A12 & 5.9 & 5.8 & 5.8 & 6.1 & -5.2 & 0.1 & -4.9 & 2.1 & -5.3 & -5.3 & 0.1 & & -4.9 & -4.9 & 1.9 & 1.9 \\
\hline A13 & 13.0 & 13.1 & 13.1 & 12.8 & -2.3 & 9.7 & 1.5 & 12.2 & -2.4 & -2.3 & 9.7 & 9.7 & & 1.3 & 12.1 & 12.1 \\
\hline A14 & 12.9 & 13.0 & 13.1 & 12.8 & -2.3 & 9.7 & 0.0 & 12.2 & -2.4 & -2.4 & 9.7 & 9.7 & -1.2 & & 12.0 & 12.1 \\
\hline A15 & 7.4 & 7.4 & 7.5 & 7.4 & -7.9 & 2.2 & -7.4 & 4.1 & -8.0 & -8.0 & 2.2 & 2.2 & -7.5 & -7.4 & & 1.6 \\
\hline A16 & 7.3 & 7.3 & 7.4 & 7.3 & -7.9 & 2.1 & -7.4 & 1.8 & -8.0 & -8.0 & 2.1 & 2.1 & -7.5 & -7.4 & -1.4 & \\
\hline
\end{tabular}

Source: own estimations

Note: t-statistics are given in the cells. A1: Single-product. A2: Multi-product (brand). A3: Multi-product (group). A4: Market segment collusion. A5: MMC1. A6: MMC2. A7: MMC3. A8: MMC4. A9: MMC5. A10: MMC6. A11: MMC7. A12: MMC8. A13: MMC9. A14: MMC10. A15: MMC11. A16: MMC12. These assumptions are explained in more detail in the text above. 
The interpretation of the above finding is not so straightforward. Ford, GM and DaimlerChrysler have got extensive multimarket contacts with each other, at the same time they individually dominate all market segments, so that the collusive behaviour found on the basis of the above test could be attributed to the highly concentrated nature of the US light vehicles market, which could also foster collusive behaviour. Another interpretation of the result could be that the collusive behaviour can be facilitated in case of both multimarket contact presence and high market concentration, and it could be even higher than in case of only multimarket contact presence, or only high market concentration. Concentration in a particular market may foster a slack, which is transferred through the multimarket contact to the other markets.

The above test for non-nested hypotheses is based upon the assumption that one of the nested models is correctly specified. It might be, however, not the case. That is why, for robustness checks, I have also tried to perform the model selection test by Rivers and Vuong (2002). However, I have been unable to get any conclusive results.

The results from testing procedures are, thus, not quite satisfactory. The test for non-nested hypothesis by MacKinnon, White and Davidson (1983) could give some support for collusive behaviour in the US car market. Whether this is a plausible result, is another question which is also difficult to answer given the absence of the publicly available cost data.

It could be argued that the US automobile market has become quite competitive recently. As a result, it is difficult to expect healthy profits in the industry. Although this argument is quite a natural argument given the current financial situation of the US automobile producers, several arguments could be named to support the results of this paper. First, 2001-2003 period, although quite competitive, is still less competitive than the subsequent and current period, when all Big Three American car producers face severe financial problems. Furthermore, the markups estimated on the basis of structural models and the markups calculated on the basis of the accounting data that appear sometimes in public could be quite different. ${ }^{40}$ In addition, several studies find collusive behaviour in the automobile industry notwithstanding the increased competition (e.g., Jaumandreu and Moral, 2006). It would be good to conduct a similar analysis for the earlier period of time if the data are available, for example, for the time period before 2000, to try to get more support for the findings of this paper.

It should be noted that the multi-product (group) specification, which captures the effect of the cross-ownership and the impact of owing several brands by the manufacturer group on the firm behaviour has not been found to be the most preferred supply-side specification on the basis of the test for the non-nested hypotheses. It seems as if the brands relevant for the US car market manufacturer groups include minor brands that may be not of great importance in determining the firms' equilibrium behaviour.

\section{Testing shock effects}

Testing shock effects to make some inferences about the mutual forbearance hypothesis largely depends on the results of the choice of the supply-side specification that best describes the data. ${ }^{41}$ The plausible estimates of own- and cross-price elasticities, mark-ups and, consequently, marginal costs are likely to determine the simulation results.

\footnotetext{
40 Verboven (1997) also in particular argues that the price-cost margins calculated on the basis of the accounting data should be treated with caution while evaluating market power in an industry. The estimation of an oligopoly model gives an indirect way to determine market power.

41 The results from these simulations may be to some extent equivalent to those from the estimation of the "conjectures", i.e., own- and cross-market reactions in the homogenous goods case.
} 
Testing shock effects could probably help me disentangle the effects from concentration and multimarket contact on pricing. Two types of shocks can be distinguished: specificmarket shocks (to study multimarket contact effects, to study the impact on other markets) and industry-level shocks (to study concentration effects, to see whether there is an impact on all markets in the industry). This analysis could be done to study the mutual forbearance hypothesis on the basis of the multimarket contact assumption that gets most support in the first step. If some other pricing equilibrium turns out to be supported by the data, strategic interactions of firms could be still investigated.

As I have mentioned before, the price war can be approximated by the changes in the ownership matrix for a particular market segment. Thus, even if I test, for example, multimarket contact assumption at the firm level, I can simulate what happens when the firm behaviour in one market segment becomes more competitive and whether this will influence the firm(s)' behaviour in the other market segments as well as where these changes will be most pronounced.

On the basis of the above described simulations in practice, I have failed to derive some conclusive evidence. I could perhaps derive more reasonable simulation results on the basis of the random coefficients framework for the demand side.

\section{Concluding remarks}

To the best of my knowledge, this is the first study on the automotive industry, which concentrates on studying various sources of the market power in an extensive way: fewness (a few competitors and large concentration), differentiation (products have unique features), market-specific collusion, and collusion due to the multimarket contact presence, and which exclusively concentrates on studying the firms' equilibrium interactions in the US car market. The mutual forbearance hypothesis is tested in the industry characterized by extensive multimarket contact, however, in which it is not so easy to test for the multimarket contact effects on collusive behaviour.

It has been found that multimarket contact may influence competition in the automobile markets and increase the firms' strategic interdependence. This effect is, however, difficult to disentangle from the effect of the market concentration in the US automobile market on the firm behaviour. It should be noted that in general the empirical studies find it problematic to distinguish between internal (e.g., concentration) and external (e.g., multimarket contact) effects on the firm behaviour. The model specifications of single-product and multiproduct firm behaviour for the car producers have been found to be among the most preferred supplyside model specifications on the basis of the information criteria and sum of squared residuals, but not on the basis of the test for non-nested hypotheses. The test by MacKinnon, White and Davidson (1983) showed some support for the specification where GM, Ford and DaimlerChrysler behave in a cooperative way, and all other automotive players behave competitively. On the basis of the model selection test by Rivers and Vuong (2002) it was difficult to choose the best supply-side specification. Therefore, one should be careful in applying a particular statistical test and interpreting its results. It seems worthwhile to compare the results from several testing procedures as robustness checks for the "best" chosen supply-side specification.

The major novelty of this paper compared to the other empirical studies on the mutual forbearance hypotheses is the specification of coalitions of multimarket contact firms and testing collusive assumptions among them. The test has been applied in a non-traditional setup as compared to the "traditional" one for such studies industries and markets (e.g., banking, or airlines). This paper has rather concentrated on testing the existence of the significant and positive impact of multimarket contact on the firm behaviour. Namely, it has been tested that 
the firms behave perfectly collusively because of multiple market presence. The degree of collusive behaviour is assumed to be the same in all the markets where the rivals meet each other. The precise quantification of the multimarket contact effect on the firm behaviour is difficult on the basis of this approach.

The results of this paper may be improved in the future by estimating more flexible substitution patterns, which may lead to the more plausible mark-ups and marginal costs estimates, and probably more reasonable results of simulating collusive behaviour due to multimarket contact. A less competitive time period could be considered using the same approach. It would also be worthwhile to have the data for a longer time period, where there may be periods of collusive and more competitive behaviour among the multimarket contact firms.

Some policy implications may be derived for conducting competition policy. The possible anticompetitive effects of the multimarket contact will have to be taken into account while setting up the antitrust policy (e.g., there may be implications for the entry of new firms), and assessing the effects of the conglomerate mergers. If the markets are strategically linked, then policy makers should take into account both direct effects of their regulatory actions in one particular market, and indirect effects in the other markets. The sole market assumption by the regulators may, thus, be irrelevant. The measurement of the competitive pressure in an industry can be more complicated than it could be inferred from the concentration ratio, or Herfindahl index, if accounting for the multimarket contact effects.

To sum up, the results of the study allow the verification of the theoretical predictions about the mutual forbearance hypothesis to a certain extent, give empirical evidence on the intermarket relationships of the multiproduct firms and contribute to the literature on the market power. Furthermore they help to explore the competitive interactions in the automotive industry, thus gaining a deeper understanding of the pricing behaviour in the automobile market which constantly receives a lot of public interest.

\section{References}

Akaike, H. (1973), Information Theory and an Extension of the Likelihood Ratio Principle, in: Petrov B.N. and F. Csaki (Eds.), Proceedings of the Second International Symposium of Information Theory, Budapest: Akademiai Kiado, 257-281.

Akaike, H. (1974), A New Look at the Statistical Model Identification, IEEE Transactions and Automatic Control AC-19, 716-723.

Alley, W. A. (1997), Partial Ownership Arrangements and Collusion in the Automobile Industry, Journal of Industrial Economics, 45(2), 191-205.

Anderson, S. and A. de Palma (1992), Multiproduct Firms: a Nested Logit Approach, Journal of Industrial Economics, Vol. XI, 261-276.

Bernheim, B. D. and M. D. Whinston (1990), Multimarket Contact and Collusive Behaviour, RAND Journal of Economics, 21(1), 1-26.

Berry, S. (1994), Estimating Discrete Choice Models of Product Differentiation, RAND Journal of Economics, Vol. 25, 242-262.

Berry, S., J. Levinsohn and A. Pakes (1995), Automobile Prices in Market Equilibrium, Econometrica, 63(4), 841-890.

Berry, S., J. Levinsohn and A. Pakes (1999), Voluntary Export Restraints on Automobiles: Evaluating a Trade Policy, American Economic Review, 89(3), 400-430. 
Bishop, S. and M. Baldauf (2006), Theoretische Grundlagen und Praktische Anwendung Wettbewerbsökonomischer Methoden in Bezug auf die Abgrenzung des relevanten Marktes und Fragen zur Praktischen Anwendbarkeit der Herfindahl-Hirschman Indexes zur Ermittlung des Konzentrationsgrades, RBB Economics.

Bonnet, C., P. Dubois and M. Simioni (2006), Two-part Tariffs Versus Linear Pricing between Manufacturers and Retailers: Empirical Tests on Differentiated Products Markets, CEPR Discussion Paper No 6016.

Brenkers, R. and F. Verboven (2006a), Liberalizing a Distribution System: the European Car Market, Journal of the European Economic Association, 4(1), 216-251.

Brenkers, R. and F. Verboven (2006b), Market Definition with Differentiated Products: Lessons from Car Market, in J. P. Choi (Eds.), Recent Developments in Antitrust: Theory and Policy.

Bresnahan, T. F. (1981), Departures from Marginal-Cost Pricing in the American Automotive Industry: Estimates for 1977-1978, Journal of Econometrics, Vol. 17, 201-227.

Bresnahan, T. F. (1987), Competition and Collusion in the American Automotive Industry: the 1955 Price War, Journal of Industrial Economics, 35(4), The Empirical Renaissance in Industrial Economics, 457-482.

Bresnahan, T. F. (1989), Empirical Studies of Industries with Market Power, in: Schmalensee, R. and R. D. Willig (Eds.), Handbook of Industrial Organization, Vol. II, Elsevier Science Publishers B.V.

Bresnahan, T. F., S. Stern and M. Trajtenberg (1997), Market Segmentation and the Sources of Rents from Innovation: Personal Computers in the Late 1980s, RAND Journal of Economics, 28(0), Special Issue in Honor of Richard E. Quandt, S17-S44.

Bulow, J. I., J. D. Geanakoplos and P. D. Klemperer (1985), Multimarket Oligopoly: Strategic Substitutes and Complements, Journal of Political Economy, 93(3), 488-511.

Caplin, A. and B. Nalebuff (1991), Aggregation and Imperfect Competition: on the Existence of Equilibrium, Econometrica, Vol. 59, 26-61.

Deutsche Bank (2004), Global Automotive Industry. The Drivers: How to Navigate the Auto Industry, Deutsche Bank Global Equity Research.

Edwards, C. (1955), Conglomerate Business as a Source of Power, in: National Bureau of Economic Research, Business Concentration and Price Policy, Princeton University Press.

Evans, W. N. and I. N. Kessides (1994), Living by the “Golden Rule”: Multimarket Contact in the U.S. Airline Industry, Quarterly Journal of Economics, 109(2), 341-366.

Farrell, J. and C. Shapiro (1990), Asset Ownership and Market Structure in Oligopoly, RAND Journal of Economics, 21(2), 275-292.

Feenstra, R. C. and J. A. Levinsohn (1995), Estimating Markups and Market Conduct with Multidimensional Product Attributes, Review of Economic Studies, 62(1), 19-52.

Gasmi, F., J.-J. Laffont and Q. H. Vuong (1990), A Structural Approach to Empirical Analysis of Collusive Behaviour, European Economic Review, Vol. 34, 513-523.

Gasmi, F., J.-J. Laffont and Q. H. Vuong (1992), Econometric Analysis of Collusive Behaviour in a Soft-Drink Market, Journal of Economics and Management Strategy, 1(2), 277-311.

Gelfand, M. D. and P. T. Spiller (1987), Entry Barriers and Multiproduct Oligopolies: Do They Forbear or Spoil?, International Journal of Industrial Organization, Vol. 5, 101-113. 
Goldberg, P. K. and F. Verboven (2001), The evolution of the Price Dispersion in the European Car Market, Review of Economic Studies, Vol. 68, 811-848.

Hausman, J. (1996), Valuation of New Goods under Perfect and Imperfect Competition, in Bresnahan, T. and R. Gordon (Eds.), The Economics of New Goods, Studies in Income and Wealth, Vol. 58, Chicago: National Bureau of Economic Research.

Hausman, J. and D. McFadden (1984), Specification Tests for the Multinominal Logit Model, Econometrica, 52 (5).

Haveman, H. A. and L. Nonnemaker (2000), Competition in Multiple Geographic Markets: the Impact on Growth and Market Entry, Administrative Science Quarterly, 45(2), 232-267.

Heggestad, A. A. and S. A. Rhoades (1978), Multi-Market Interdependence and Local Market Competition in Banking, Review of Economics and Statistics, 60(4), 523-532.

Ivaldi, M. and F. Verboven (2005), Quantifying the Effects from Horizontal Mergers in European Competition Policy, International Journal of Industrial Organization, 23 (9-10), 669-691.

Jans, I. and D. I. Rosenbaum (1996), Multimarket Contact and Pricing: Evidence from the U.S. Cement Industry, International Journal of Industrial Organization, Vol. 15, 391-412.

Jaumandreu, J., and J. Lorences (2002), Modelling Price Competition Across Many Markets: an Application to the Spanish Loans Market, European Economic Review, Vol. 46, 93-115.

Jaumandreu, J. and M. J. Moral (2006), Identifying Behaviour in a Multiproduct Oligopoly: Incumbents Reaction to Tariffs Dismantling, Munich Personal RePEc Archive (MPRA) Paper No 1248.

Jayaratne, J. and C. Shapiro (2000), Simulating Partial Asset Divestitures to "Fix" Mergers, International Journal of the Economics of Business, 7(2), 179-200.

MacKinnon, J. G., H. White and R. Davidson (1983), Tests for Model Specification in the Presence of Alternative Hypotheses: Some Further Results, Journal of Econometrics, Vol. 21, 53-70.

Matsushima, H. (2001), Multimarket Contact, Imperfect Monitoring and Implicit Collusion, Journal of Economic Theory, Vol. 98, 158-178.

McFadden, D. (1978), Modelling the Choice of Residential Allocation, in: Karlqvist, A., L. Lundqvist, F. Snickars and J. W. Weibull (Eds.), Spatial Interaction Theory and Planning Methods, in: Series Andersson, A. and W. Isard (Eds.), Studies in Regional Science and Urban Economics, Vol. 3, North-Holland Publishing Company.

Nevo, A. (1997), Mergers with Differentiated Products: the Case of Ready-to-Eat Cereal, Competition Policy Center Paper CPC99002, University of California, Berkeley.

Nevo, A. (1998), Identification of the Oligopoly Solution Concept in a DifferentiatedProducts Industry, Economic letters, 59, 391-395.

Nevo, A. (2001), Measuring Market Power in the Ready-to-Eat Cereal Industry, Econometrica, 69(2), 307-342.

Odagiri, H. and H. Yamawaki (1986), A Study of Company Profit-Rate Time Series: Japan and the United States, International Journal of Industrial Organization, Vol. 4, 1-23.

Pagan, A. R. and A. D. Hall (1983), Diagnostic Tests as Residual Analysis, Econometric Reviews, Vol. 2, 159-218. 
Parker, P. M. and L.-H. Roller (1997), Collusive Conduct in Duopolies: Multimarket Contact and Cross-Ownership in the Mobile Phone Industry, RAND Journal of Economics, 28(2), 304-322.

Petrin, A. (2002), Quantifying the Benefits of New Products: the Case of the Minivan, Journal of Political Economy, 110(4).

Phillips, O. R. and C. F. Mason (1992), Mutual Forbearance in Experimental Conglomerate Markets, RAND Journal of Economics, 23(3), 395-414.

Phillips, O. R. and C. F. Mason (1996), Market Regulation and Multimarket Contact Rivalry, RAND Journal of Economics, 27(3), 596-617.

Requena-Silvente, F. and J. Walker (2005), Competition and Product Survival in the UK Car Market, Applied Economics, Vol. 37, 2289-2295.

Reynolds, R. J. and B. R. Snapp (1986), The Competitive Effects of Partial Equity Interests and Joint Ventures, International Journal of Industrial Organization, Vol. 4, 141-153.

Rivers, D. and Q. Vuong (2002), Model Selection Tests for Nonlinear Dynamic Models, Econometrics Journal, Vol. 5, 1-39.

Scherer, F. M. and D. Ross (1990), Industrial Market Structure and Economic Performance, Houghton Mifflin Company, Boston, MA.

Schwarz, G. (1978), Estimating the Dimension of a Model, Annals of Statistics, 6(2), 461464.

Scott, J. T. (1982), Multimarket Contact and Economic performance, Review of Economics and Statistics, 64(3), 368-375.

Solomon, E. H. (1970), Bank Merger Policy and Problems: A Linkage Theory of Oligopoly, Journal of Money, Credit and Banking, 2(3), 323-336.

Spagnolo, G. (1999), On Interdependent Supergames: Multimarket Contact, Concavity and Collusion, Journal of Economic Theory, 89(1), 127-139.

Sudhir, K. (2001), Competitive Pricing Behaviour in the Auto Market: a Structural Analysis, Marketing Science, 20(1), 42-60.

Tomas, C. J. and R. D. Willig (2006), The Risk of Contagion from Multimarket Contact, International Journal of Industrial Organization, 24(6), 1157-1184.

Verboven, F. (1996), International Price Discrimination in the European Car Market, RAND Journal of Economics, 27(2), 240-268.

Verboven, F. (1997), Testing for Monopoly Power When Products are Differentiated in Quality, WZB Discussion Paper FS IV 97-2, Wissenschaftszentrum Berlin.

Verboven, F. (1998), Localized Competition, Multimarket Operation, and Collusive Behaviour, International Economic Review, 39(2), 371-398.

Verboven, F. (1999), Product Line Rivalry and Market Segmentation - With an Application to Automobile Optional Engine Pricing, Journal of Industrial Economics, 47(4), 399-425.

Verboven, F. (2002), Quantitative Study to Define the Relevant Market in the Passenger Car Market, European Commission Final Report.

Vuong, Q. H. (1989), Likelihood Ratio Tests for Model Selection and Non-nested Hypothesis, Econometrica, 57(2), 307-333. 
Werden, G. J. and L. M. Froeb (1994), The Effects of Mergers in Differentiated Products Industries: Logit Demand and Merger Policy, Journal of Law, Economics and Organization, 10(2), 407-426.

Werden, G. J. and L. M. Froeb (2002), The Antitrust Logit Model For Predicting Unilateral Competitive Effects, Antitrust Law Journal, 70(1).

Yamawaki, H. (1989), A Comparative Analysis of Intertemporal Behaviour of Profits, Japan and the United States, Journal of Industrial Economics, Vol. 37, 389-409.

\section{Appendix. Tests for non-nested hypotheses}

\subsection{MacKinnon, White and Davidson (1983) test for non-nested hypotheses}

These tests fall under the category of "artificial testing". 42 Two non-nested models are embedded into a more general artificial model. MacKinnon, White and Davidson (1983) derive the test for the linear case (J-test), the non-linear case (P-test), with transformed dependent variables and in case of the IV estimation.

I can re-write the below pricing equation, which is derived from the first-order conditions and can be decomposed into marginal cost and markup:

$p=c+\Omega^{-1} S$

in the following way:

$p=w \gamma+D \lambda+\omega+\Omega^{-1} s$

where $w$ are product characteristics, $D$ are firm dummies, $\omega$ are unobserved product characteristics. The quality-adjusted prices will then be:

$\pi=p-w \gamma-\omega=D \lambda+\Omega^{-1} s$

The null hypothesis can be formulated as follows:

$H_{0}: p=w \gamma_{0}+\pi_{0}+\varepsilon_{0}$

The alternative hypothesis can be written down as:

$H_{1}: p=w \gamma_{1}+\pi_{1}+\varepsilon_{1}$

If the model under $H_{0}$ is a true model, then there should be no correlation between its residuals and the difference between the fitted values of $H_{0}$ and $H_{1} \cdot w$, i.e., product characteristics, will be the same in case of both models, thus, the quality-adjusted prices $\pi_{0}$ and $\pi_{1}$ will be the fitted values of interest.

The idea of the P-test is to evaluate whether $p-\hat{\pi}_{0}$ is orthogonal to $\hat{\pi}_{1}-\hat{\pi}_{0}$. For that purpose, the artificial regression should be run:

$\left(p-\hat{\pi}_{0}\right)=w a+\left(\hat{\pi}_{1}-\hat{\pi}_{0}\right) b+u$

where $a$ and $b$ are the parameters to be estimated. The pairs of models are compared on the basis of the t-statistic, which is normally distributed.

$42 \quad$ This test has been in particular applied by Feenstra and Levinsohn (1995) and Verboven (2002). 


\subsection{Rivers and Vuong (2002) model selection test}

Assume the following cost specification: ${ }^{43}$

$c_{j}^{h}=\exp \left(w_{j} \gamma+\omega_{j}^{h}\right)$

Taking the logarithms on both sides I get:

$\ln c_{j}^{h}=\omega_{j} \gamma+\omega_{j}^{h}$

or

$\ln \left(p_{j}-\Omega^{-1} s\right)=w_{j} \gamma+\omega_{j}$

It is assumed that two models $h$ and $h^{\prime}$ are tested against each other:

$p_{j}=c_{j}^{h}+\left(\Omega^{-1} s\right)^{h}$

and

$p_{j}=c_{j}^{h^{\prime}}+\left(\Omega^{-1} s\right)^{h^{\prime}}$

The lack-of-fit criteria are defined for both models as:

$\min Q_{n}^{h}=\min \frac{1}{n} \sum\left(\varpi_{j}^{h}\right)^{2}=\min \frac{1}{n} \sum\left(\ln \left(p_{j}-\Omega^{-1} s\right)-w_{j} \gamma\right)^{2}$

The null hypothesis is defined as the two models are asymptotically equivalent when

$H_{0}: \lim _{n \rightarrow \infty}\left(\bar{Q}_{n}^{h}-\bar{Q}_{n}^{h^{\prime}}\right)=0$

The two alternative hypotheses are that model $h$ performs asymptotically better than model $h^{\prime}$, or that model $h^{\prime}$ performs asymptotically better than model $h$.

The test statistic is then calculated in the following way:

$T_{n}=\frac{\sqrt{n}}{\bar{\sigma}^{2}}\left\{\bar{Q}_{n}^{h}-\bar{Q}_{n}^{h^{\prime}}\right\}$

where $\bar{Q}_{n}^{h}, \bar{Q}_{n}^{h^{\prime}}$ are the sample-of-lack criteria that are estimated for the models $h$ and $h^{\prime}$ at the estimated parameters values of the model, and $\hat{\sigma}^{2}$ is the estimated value of the variance of the difference in the lack-of-fit. The test statistic has an asymptotic standard normal distribution.

If the standardized difference is statistically negative that implies that the model $h$ is better than model $h^{\prime}$. If the test statistic is large and positive that means that the model $h^{\prime}$ is better than model $h$.

43 Vuong-type tests have been in particular applied by Jaumandreu and Lorences (2002), Bonnet et al. (2006), and Jaumandreu and Moral (2006). 